\title{
Morfodynamika i tempo erozji klifu w Trzęsaczu (1997-2017)
}

\author{
Morphodynamics and rate of cliff erosion in Trzęsacz (1997-2017)
}

\author{
Tomasz A. Łabuz* \\ Instytut Nauk o Morzu, Uniwersytet Szczeciński; *tomasz.labuz@usz.edu.pl
}

\begin{abstract}
Zarys treści: Na podstawie pomiarów morfologicznych klifu i plaży oraz dokumentacji fotograficznej ustalono współczesne tempo erozji klifu w miejscowości Trzęsacz w latach 1997-2017. Zarejestrowane zmiany geodynamiczne klifu powiązano z cyklicznymi czynnikami sprawczymi: spiętrzeniami sztormowymi i opadami deszczu. Ponadto przedstawiono historyczne zmiany morfodynamiczne klifu i niszczenia kościoła w oparciu o dostępne publikacje, mapy i fotografie. Od 2003 r. ruinę chroni ścianka szczelna z gabionów - klif w tym miejscu jest nieaktywny. Od 2010 r. podnóże klifu Wybrzeża Trzebiatowskiego od Niechorza do Trzęsacza osłonięte jest opaską, to zatrzymało znaczną erozję rejestrowaną na całym odcinku do $2009 \mathrm{r}$. Ustalono, że zabieg ten nie chroni przed cofaniem krawędzi klifu, wynoszącym do 0,1 $\mathrm{m} \mathrm{a}^{-1}$ tuż przy ruinie kościoła. Na ostatnim 200-stu metrowym odcinku bez opaski średnie tempo cofania krawędzi wynosi 0,4 $\mathrm{m} \mathrm{a}^{-1}$.
\end{abstract}

Słowa kluczowe: morenowe wybrzeże klifowe, osuwiska, tempo erozji klifu, spiętrzenia sztormowe, opady, Wybrzeże Trzebiatowskie

\begin{abstract}
In the article it has been presented historical and present morphodynamic change the of the morainic cliff in the region of Trzęsacz on the west Polish Baltic coast. Historical cliff and church erosion have been described basing on available publications, maps and photographs. On the basis of field morphological measurements, current rate of cliff erosion was determined for period 1997-2017. The recorded geodynamical cliff changes of the have been related to the periodic impact factors: storm surges and precipitation. Since 2003, the ruin has been protected by a wall made of gabions - the cliff is inactive. Since 2010, the foot of the cliff of the Trzebiatów Highland from Niechorze to Trzęsacz is shielded with a rocky band. This protection has stopped significant cliff erosion recorded until 2009. It was found that this treatment does not protect against the cliff edge retreat, that is up to $0.1 \mathrm{~m}$ per year near the church ruin. Along the last $200 \mathrm{~m}$ long cliff section without band, the average cliff edge retreat is $0.4 \mathrm{~m}$ annually.
\end{abstract}

Key words: moraine cliff shore, landslides, cliff erosion rate, storm surges, precipitation, Trzebiatów highland shore

\section{Wstęp}

Wybrzeże klifowe w Polsce zajmuje $65 \mathrm{~km}$ na 500 km długości całkowitej brzegu (Subotowicz 1982, Łabuz 2012a). Typowe klify nadmorskie utworzone są w polodowcowych utworach morenowych i fluwioglacjalnych (czasem zastoiskowych). Zbudowane są z różnorodnego materiału: glin, iłów, torfów, żwirów i piasków. Powstały w wyniku podcinania przez fale morskie wysoczyzn morenowych, utworzonych z osadów polodowcowych. Wysokość wysoczyzn i rodzaj budujących je struktur decydują o wysokości ściany klifu, jego nachyleniu, kierunku rozwoju, obecności warstw uwodnionych, objętości osadu obsuwanego i odporności na niszczenie. Najbardziej wyczerpującą publikacją omawiającą rozmieszczenie, budowę i dynamikę wybrzeży klifowych polskiego wybrzeża jest praca Subotowicza (1982).

Rozwój nowoczesnych technologii i logistyczne rozwiązania techniczne pomiarów geodezyjnych ukształtowania terenu pokazują ewolucję metodyki badań klifów: od obserwacji i pomiarów w oparciu o repery (Dobracki, Racinowski 1989, Racinowski i in. 1993, Winowski 2008), niwelacyjne profile poprzeczne klifu (Musielak i in. 2005, Florek i in. 2008), poprzez kompleksowy monitoring na zlecenie służb państwowych (Łabuz 2012a) do technik cyfrowych i pomiarów w oparciu o technologie GPS oraz laserowe naziemne TLS in situ (Kolander 2013, Kolander i in. 2013, Łabuz 2014, Uścinowicz i in. 


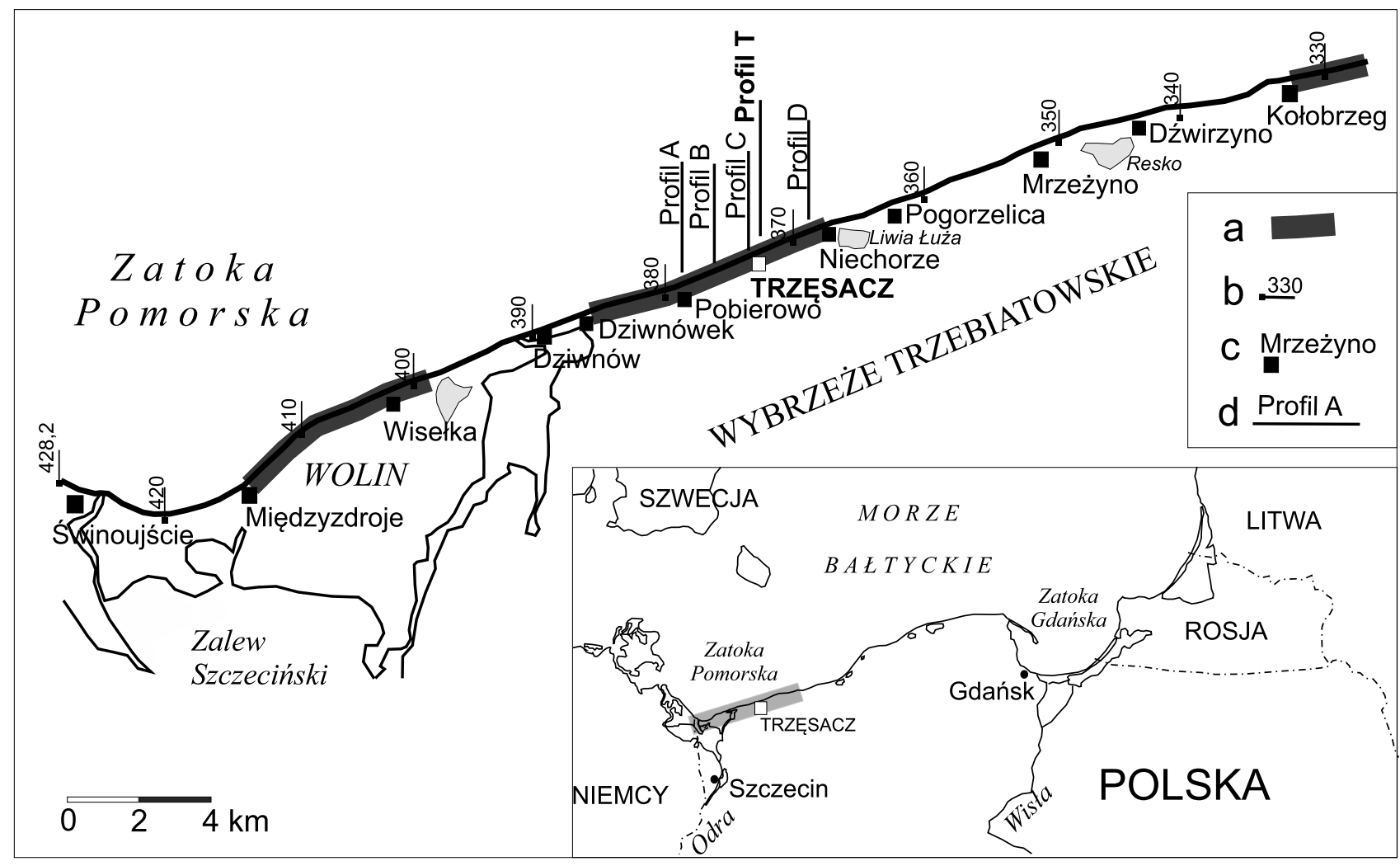

Ryc. 1. Zachodnie wybrzeże Polski i lokalizacja klifu w Trzęsaczu

a - odcinki klifowe, c - kilometraż brzegu, c - miejscowości, d - profile A-D (ryc. 4) i profil T w Trzęsaczu (ryc. 9)

Fig. 1. West Polish coast with cliff location in Trzęsacz

A - cliff coast, B - coast kilometrage, C - settlement, D - profiles A-D (Fig. 4) and profile T in Trzęsacz (Fig. 9)

2014, Kostrzewski i in. 2015, Suchocki i in. 2016, Frydel i in. 2017) oraz zdalne: lotnicze skanowanie laserowe, zdjęcia lotnicze lub satelitarne (Dudzińska-Nowak, Furmańczyk 2005, Dudzińska-Nowak, Wężyk 2014). Współcześnie, w XXI w. bezinwazyjne metody kartowania rzeźby klifu umożliwiają analizę stromych i trudno dostępnych ścian klifowych. Efektem tych prac są wyniki przedstawiające tempo erozji klifu na różnych odcinkach wybrzeża (Kolander i in. 2013, Uścinowicz i in. 2014, Suchocki i in. 2016, Frydel i in. 2017).

Problematyka dynamiki klifowego odcinka Wybrzeża Trzebiatowskiego (ryc. 1), na którym położony jest analizowany fragment klifu była przedmiotem badań głównie w latach 80. i 90. XX w. (Kopczyńska-Lamparska 1974, Dobracka, Ruszała 1988, Dobracki, Racinowski 1989, Racinowski 1990, Racinowski i in. 1993, Dobracka, Dobracki 1995, Dobracki 1995, Rotnicki 1995, Tomczak 1995, Racinowski i in. 1995, Racinowski 1996b, Dobracki i in. 1999, Racinowski, Pozlewicz 2000). W ostatnich latach nie prowadzono badań na tym odcinku wybrzeża klifowego, co jest istotne ze względu na intensywny rozwój zabudowy przy jego krawędzi, penetracje turystyczne i różnorodne działania tzw. ochrony brzegu, stosowane od 15 -stu lat w celu zahamowania abrazji. Intensywność erozji wybrzeża klifowego pomiędzy Niechorzem a Dziwnówkiem jest zróżnicowana. Według Musielaka (1995) ten odcinek należy do brzegu abrazyjnego $\mathrm{z}$ dużymi i średnimi zmianami. Ustalono, że zmiany morfodynamiczne nadbrzeży i plaż różnią się na poszczególnych odcinkach i są związane przede wszystkim $z$ okresowymi spiętrzeniami sztormowymi (Dudzińska-Nowak, Furmańczyk 2005, Musielak i in. 2005). Ruiny kościoła św. Mikołaja w Trzęsaczu są dobrym wskaźnikiem zachodzącej erozji klifu. W międzyczasie powstało wiele nowych prac dotyczących badań geodynamiki najwyższego klifu na wyspie Wolin (Kostrzewski, Zwoliński 1995, Kolander i in. 2013, Kostrzewski i in. 2015, Winowski $2008,2015)$ i innych odcinków klifowych otwartego morza (Florek i in. 2008, Uścinowicz i in. 2014, Suchocki i in. 2016).

Celem niniejszej pracy jest określenie zmian morfodynamicznych klifu morenowego w Trzęsaczu w okresie 1997-2017, wyznaczenie tempa erozji i miejsc, w których ona zachodzi oraz wskazanie czynników sprawczych, w tym działań antropogenicznych stosowanych $\mathrm{w}$ celu zatrzymania erozji. Ponadto $\mathrm{w}$ artykule przedstawiono historyczne tło i wiedzę o tempie zmian położenia krawędzi klifu do czasów współczesnych oraz oceniono zasadność zastosowanych metod ochrony klifu. 


\section{Uwarunkowania i typy rozwoju morenowego wybrzeża południowego Bałtyku}

Budowa geologiczna i wysokość nadbrzeża morenowego (klifowego - wg istniejącej nomenklatury) są głównymi uwarunkowaniami omawianej dynamiki wybrzeża klifowego.

Subotowicz (1982) wyróżnia trzy geodynamiczne typy klifu (ryc. 2):

- osypiskowy,

- obrywowy,

- osypiskowo-zsuwowy (spływowy).

Typ osypiskowy (A) powstaje w utworach luźnych, a nachylenie stoku jest mniejsze. Najczęściej na glinach morenowych zalegają piaski fluwioglacjalne, które są szybciej erodowane niż bardziej odporna stopa klifu. Jego podnóże podcinane przez morze skutkuje powstawaniem licznych osuwisk. Koluwium na plaży może pokrywać powierzchnię rzędu $380 \mathrm{~m}^{3}$, jak wykazano podczas badań klifów wyspy Wolin (Winowski 2008). Osad piaszczysty ze ścian klifu zasila plażę u podnóża, która okresowo chroni je przed rozmywaniem sztormowym.

Typ obrywowy (B) - to klify o mniejszej wysokości, charakterystyczne dla omawianego odcinka brzegu, zbudowane z glin jedno- lub dwudzielnych, o różnych parametrach geologicznych. Klif taki, w wyniku większych sił spójności (kohezji drobnego osadu) może mieć nachylenie od 60 do 80 stopni; powstają wtedy pionowe ściany. Po przekroczeniu naturalnego kąta nachylenia tworzą się osuwiska nazywane obrywami. W dolnej części powstają nisze abrazyjne, które po zapadnięciu powodują gwałtowne cofanie lub obniżanie górnej krawędzi klifu (Racinowski

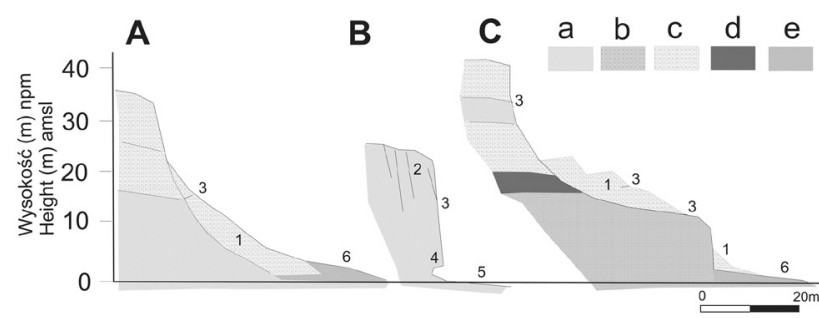

Ryc. 2. Typy geodynamiczne klifów polskiego wybrzeża (opracowane za Subotowiczem 1982)

A - osypiskowy, B - obrywowy, C - osypiskowo-zsuwiskowy, 1 - koluwium, 2 - pęknięcia, 3 - wysięki, 4 - nisza abrazyjna, 5 - platforma abrazyjna, 6 - plaża, a - gliny brązowe, twarde, $\mathrm{b}$ - gliny szare, plastyczne, c - piaski fluwioglacjalne, $\mathrm{d}$ - utwory zastoiskowe, e - piaski plażowe

Fig. 2. Geodynamical types of cliff on the Polish coast (based on Subotowicz 1982)

A - sliding, B - detaching, C - semi-sliding and detaching, 1 - colluvium, 2 - cracks, 3 - springs, 4 - abrasion niche, 5 abrasion platform, 6 - beach, a - hard, brown clay, $b$ - plastic, gray clay, $\mathrm{c}$ - fluvioglacial sands, $\mathrm{d}$ - limnic sediments, e - beach sands $i$ in. 1995). Nagromadzenie wody gruntowej na warstwach nieprzepuszczalnych prowadzi do powstania wysięków (Dobracka, Dobracki 1995) i spływu uwodnionej gliny (sufozja). Typowa piaszczysta plaża u podnóża tego typu klifu występuje rzadko. Zbudowana jest ona ze szczątkowego residuum osadu grubszego wypłukanego z glin i posiada niewielką wysokość nad poziom morza, co sprzyja erozji już podczas niewielkich spiętrzeń sztormowych.

Typ osypiskowo-zsuwowy (C) - charakteryzuje klify o złożonej budowie geologicznej, gdzie kształt stoku zależy od odporności warstw na erozję - wietrzenie, sufozję czy abrazję. Piaski, które częściowo budują taki klif są szybciej niszczone niż sąsiednie warstwy gliny (Florek i in. 2008, Suchocki i in. 2016). Klif ten jest podmywany i mocno przekształcany przez wypływające $z$ jego warstw wody. Ten typ jest najbardziej dynamiczny, a jego przemiany są wręcz nieprzewidywalne, czego przykładem jest trwała erozja klifu w Jarosławcu, Dębinie koło Ustki czy w Jastrzębiej Górze (Florek i in. 2008, Frydel i in. 2017, Uścinowicz i in. 2014).

Ze względu na ułożenie warstw skalnych wyróżnia się:

- klif strukturalny - utworzony w warstwach nachylonych w stronę lądu,

- klif ześlizgowy - utworzony w warstwach nachylonych w stronę morza lub jeziora, oprócz procesu abrazji modeluje go również osuwanie i ześlizgiwanie się materiału skalnego.

Wyróżnione geodynamiczne typy klifu przez Subotowicza (1982) dają podstawę do interpretacji obecnych i przyszłych zmian morfologicznych badanych odcinków wybrzeża. W geosystemie nadmorskim, zwłaszcza na wybrzeżu klifowym istotne jest wyznaczanie stref bezpiecznych do inwestowania $z$ uwzględnieniem zróżnicowania procesów i uwarunkowań geologicznych (Racinowski, Pozlewicz 2000). W morfologii ściany klifu wyróżnia się stok, krawędź z jego wierzchowiną oraz podnóże (stopę klifu). Inne istotne czynniki zewnętrzne odpowiedzialne za dynamikę nadbrzeży morenowych (klifowych wybrzeży) to warunki pogodowe, głównie opad (deszcz lub śnieg), działalność człowieka (zabudowa krawędzi lub tzw. ochrona podnóża) i najważniejszy - abrazyjna działalność morza. Powodują one szereg morfologicznych zmian ścian klifowych, w tym powstawanie wysięków, osuwisk, obrywów i spływów. Najprościej jest określić tempo erozji klifu na podstawie cofania jego krawędzi. W ten sposób nie można jednak określić zmian morfologicznych wysokich ścian klifów oraz położenia ich podnóża. Erozję podnóża trudno jest oszacować ze względu na powstające koluwium, które może wydłużać stok w kierunku plaży (lub platformy abrazyjnej) i przez to zwiększać objętość spiętrzonego materiału. Erozja klifu powoduje straty lądu nadbrzeża, rozumiane jako cofanie 
krawędzi i objętościowy ubytek osadu. Zmiany te zależą zarówno od wysokości klifu jak i jego budowy geologicznej. Im bardziej podatne podłoże, tym cofanie krawędzi i podnóża zachodzi częściej i na większą skalę.

Ze względu na aktualność procesu abrazji wyróżnia się:

- klif aktywny (czynny, żywy) - podnóże położone w strefie oddziaływania i niszczenia przez fale, stoki są nagie lub skąpo porośnięte niszczone przez ruchy masowe,

- klif nieaktywny (martwy) - nie podlegający już wyraźnym procesom erozji, zwykle pokryty jest grubą warstwą osadów stokowych oraz roślinnościa,

- klif odmłodzony - klif nieaktywny, który okresowo jest podcinany przez fale podczas bardzo silnych spiętrzeń sztormowych.

W celu zachowania względnej stabilności klifu morenowego ważne jest ograniczenie wpływu człowieka, czyli ograniczenie budowy obiektów na krawędzi jego ściany. Ponadto istnienie u podnóża ściany klifu plaż o danej wysokości i szerokości ma decydujący wpływ na jego stabilność w relacji do występujących zjawisk spiętrzeń sztormowych. Im wyższa plaża (min. 3 m n.p.m.) tym większe bezpieczeństwo stabilności nadbrzeża. W celu zahamowania erozji klifów stosowany jest szereg metod i zabiegów jego ochrony. Ilość tych zabiegów i form ochrony wzrosła po 2007 r. w związku ze zwiększeniem nakładów finansowych na tzw. ochronę brzegów, pochodzących $z$ funduszy unijnych w ramach programu Infrastruktura i Środowisko. Nowe zabiegi w latach 2007-2016 zastosowano m.in. pod klifem w Gdyni-Orłowo, Jastrzębiej Górze, Jarosławcu, Ustroniu Morskim oraz na dużą skalę na Wybrzeżu Trzebiatowskim od Pustkowa do Niechorza. Ich działanie nie jest do końca właściwe i nie stabilizuje stoku klifów, czego dowodem powstające osuwiska i spływy, np. w Jarosławcu i Jastrzębiej Górze.

\section{Metody badań}

Podstawą realizacji postawionego celu badań był materiał $\mathrm{z}$ wieloletnich obserwacji zmian morfologicznych klifu morenowego i wyniki z pomiarów niwelacyjnych nadbrzeża oraz brzegu na odcinku Pustkowo-Trzęsacz-Rewal od 1997 do 2017 r. Szczegółowo przeanalizowano zmiany geodynamiczne klifu w bezpośrednim sąsiedztwie ruiny kościoła na podstawie bazowych profili niwelacyjnych wyznaczanych w poszczególnych latach do badań monitoringowych. Ponadto wykonano analizę stosowanych od 2001 r. działań polegających na powstrzymaniu erozji tego odcinka klifu, wykonywanych przez Urząd
Morski w Szczecinie. Posadowione opaski z głazów oraz refulacja plaży znacząco zmieniły naturalny przebieg procesów rozwoju wybrzeża na tym odcinku. Każda analiza przebiegu procesów naturalnych bez uwzględnienia tych zabiegów byłaby obarczona dużym błędem. $\mathrm{Z}$ ich powodu nie jest już możliwe określenie naturalnych uwarunkowań rozwoju nadbrzeża klifowego i plaży, co już w latach 60. XX w. stwierdził Bohdziewicz (1963). Podjęto jednak próbę oceny działania zastosowanych zabiegów, ponieważ są one kosztowne i należy znać ich skuteczność.

Analizę historyczną zmian położenia klifu w Trzęsaczu przeprowadzono w oparciu o dostępne publikacje oraz mapy: geologiczne w skali 1:50 000, topograficzne mapy polskie 1:10 000 i niemieckie przedwojenne $\mathrm{W}$ skali 1:25 000, a także dostępne w Internecie fotografie ukazujące niszczenie kościoła.

Analizę zmian, które zaszły w okresie 1997-2017 przeprowadzono $\mathrm{w}$ oparciu o terenowe obserwacje i pomiary niwelacyjne $\mathrm{w}$ następujących terminach: 07.1997, 09.1999, 11.2001, 01/05.2002, 11.2004, 05.2005, 12.2006, 01/02.2007, 09.2009, 09.2010, 08/10.2011，08/12.2013，05/08.2014, 01/09.2015, 01/05/12.2017. Do szczegółowych analiz zmian poło-

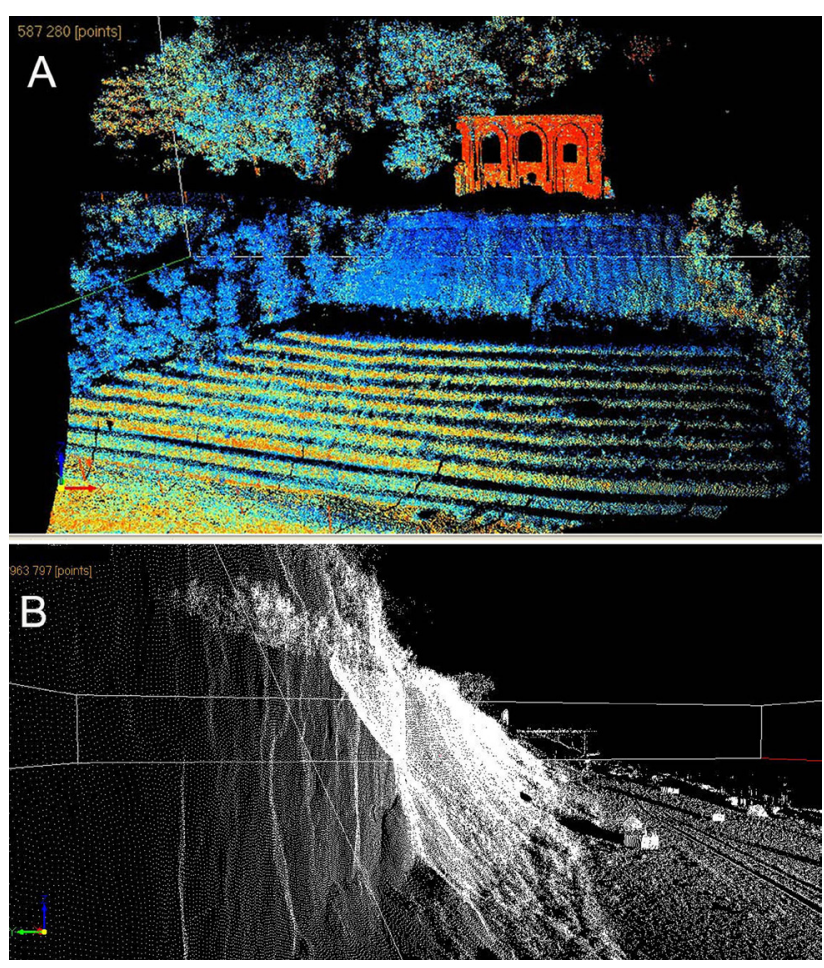

Ryc. 3. Obraz klifu na podstawie naziemnego skanowania laserowego (TLS) w 2013

A - ściana klifu osłonięta opaską z gabionów u podnóża ruiny kościoła od 2002, B - ostatni naturalny, odcinek klifu położony $250 \mathrm{~m}$ na wschód od ruiny, objęty monitoringiem

Fig. 3. Cliff image based on terrestrial laser scanning (TLS) in 2013

A - cliff slope with church ruin protected by gabion band since 2002, B - monitored part of last natural cliff located 250 m eastward from ruin 
żenia krawędzi klifu wykorzystano wyniki pomiarów niwelatorem i taśmą mierniczą. Pomiary wykonywano od znanych punktów reperowych usytuowanych przy krawędzi (drzewo, krzew lub wbity palik). Wysokość pionowej ściany klifu określano za pomocą 7-metrowej łaty geodezyjnej lub sznurka z oznaczoną skalą długości. Pomiar ten wykonywano przez plażę do linii wody, tym samym wyznaczając jej szerokość i wysokość. W różnym okresie do prac tych do wykorzystywano: tachimetr, niwelator, taśmy miernicze, dalmierz geodezyjny, a także odbiornik DGPs oraz skaner naziemny TLS.

Prace te latach 1997-2008 były wykonywane na całym Wybrzeżu Trzebiatowskim, w tym na odcinku 250 m na wschód od ruiny kościoła. W tym czasie część reperów została zniszczona w wyniku cofania klifu. W okresie 2002-2005 ustalono nowe miejsca reperowe. Na podstawie wyników tych badań powstała publikacja omawiająca zmiany dynamiczne brzegu i nadbrzeża tego odcinka do roku 2005 (Musielak i in. 2005). Od 2010 r. badania obejmowały $500 \mathrm{~m}$ długości klif $\mathrm{z}$ wybudowaną opaską z głazów $(372,8-372,9 \mathrm{~km})$ oraz ostatni naturalny odcinek bez osłony $(372,55-372,8 \mathrm{~km})$. W latach $2011-2012$ badania prowadzono na potrzeby monitoringu środowiska przyrodniczego (Łabuz 2012a).

W latach 2010-2017 wykonywano odczyty odległości od istniejących reperów od krawędzi klifu i mierzono szerokość plaż. W 2013 i 2014 wykonano pierwsze skanowania ścian klifu laserem naziemnym - TLS. Skany obejmowały ścianę klifu z ruiną kościoła oraz położony $150 \mathrm{~m}$ na wschód od niej naturalny odcinek klifu (ryc. 3). Naziemne skanowanie laserowe (TLS) umożliwiło dokładną analizę zmian powierzchni ściany klifu, w tym miejsc nieodstępnych. Wyniki zamieszczone $\mathrm{w}$ tej pracy uzupełnia dokumentacja fotograficzna (ryc. 6, 7, 8).

Badania prowadzone w sąsiedztwie ruiny kościoła pozwoliły zarejestrować skutki:

- erozji w wyniku spiętrzeń sztormowych w ciągu ostatnich 20 lat,

- osunięć klifu w wyniku intensywnych opadów,

- działań na rzecz ochrony ściany kościoła w Trzęsaczu i klifu w jego sąsiedztwie.

Wymieniane $\mathrm{w}$ pracy spiętrzenia sztormowe i maksymalny poziom morza pochodzą z zapisu mareografu portu w Kołobrzegu. Nazwy sztormów zostały nadane przez niemieckie służby meteorologiczne.

\section{Charakterystyka Wybrzeża Trzebiatowskiego}

Morenowe klify Wybrzeża Trzebiatowskiego (ryc. 1) to odcinek $17 \mathrm{~km}$ wybrzeża od Niechorza do Dziwnówka (368-385 km wg klasyfikacji wybrze- ża) (Dobracka, Ruszała 1988). Średnie wysokości klifu osiągają 12-15 m n.p.m. To jeden $z$ dłuższych odcinków morenowego klifu nadmorskiego na polskim wybrzeżu i niestety też jeden $z$ gęściej zabudowanych. Położonych jest tu kilka miejscowości, których zabudowa $\mathrm{w}$ wyniku wieloletniego cofania klifu znajduje się blisko jego krawędzi. Pomiędzy Niechorzem $(368 \mathrm{~km})$ a Rewalem $(370 \mathrm{~km})$ oraz
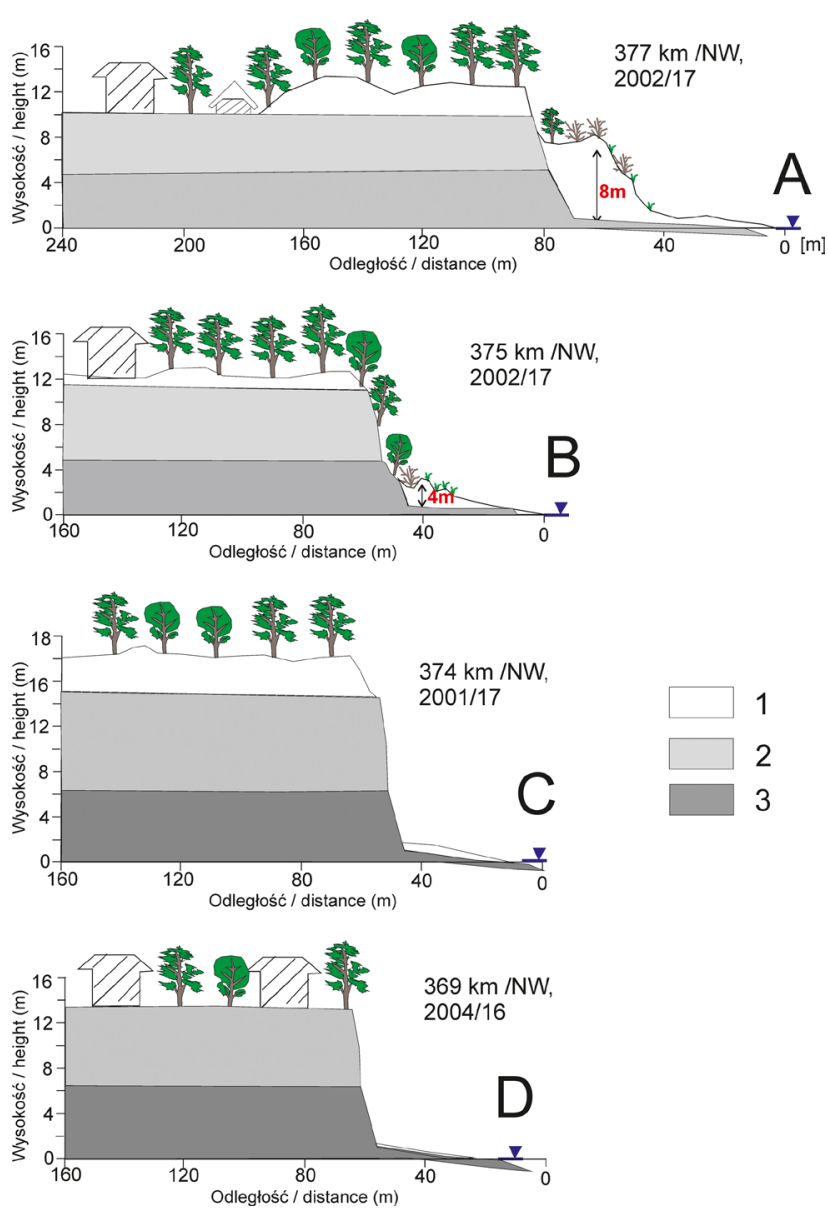

Ryc. 4. Przekroje klifowego wybrzeża trzebiatowskiego na odcinku Pobierowo - Niechorze (C i D, bez opaski istniejącej od 2010)

1 - piaski eoliczne i plażowe, 2 - gliny zwałowe zielone, 3 gliny zwałowe szare, A - morenowy klif $z$ formami eolicznymi na wierzchowinie i okresowo erodowaną dużą wydmą przednią, Pobierowo, $377 \mathrm{~km}, \mathrm{~B}$ - morenowy klif $\mathrm{z}$ formami akumulacji eolicznej na wierzchowinie i wąskim pasem niskich wydm przednich, Pustkowo, 375 km, C - aktywny klif morenowy z utworami eolicznymi na wierzchowinie, rejon Trzęsacza, 374 km, D - aktywny klif morenowy pomiędzy Trzęsaczem a Niechorzem, $369 \mathrm{~km}$

Fig. 4. Cross-sections of cliff coast of the Trzebiatów highland shore between Pobierowo and Niechorze (C \& D, without bands since 2010)

1 - aeolian and beach sands, 2 - green clay, 3 - gray clay, A moraine cliff with aeolian forms on top and periodically eroded larger foredune Pobierowo, $377 \mathrm{~km}, \mathrm{~B}$ - moraine cliff with aeolian forms on top and narrow and low foredune, Pustkowo, $375 \mathrm{~km}, \mathrm{C}$ - active moraine cliff with aeolian forms on top, near Trzęsacz, 374 km, D - active moraine cliff between Trzęsacz and Niechorze, $369 \mathrm{~km}$ 
Trzęsaczem (373 km) klif jest aktywny (ryc. 4 C, D). $\mathrm{Na}$ odcinku wybrzeża pomiędzy Pustkowem a Pobierowem klif tylko miejscami jest aktywny, przeważnie jego stok ustabilizowany jest roślinnością (375-379 km). Osłania go od 1 do 2 wałów wydmowych o wysokości bezwzględnej 3-4 m n.p.m. (ryc. 4 A, B). Od Pobierowa do Łukęcina klif ma wysokość 8 m n.p.m. i najczęściej jest aktywny (380-385 km). Okresowo u jego podnóża rozwijają się embrionalne formy wydmowe, które niszczone są przez spiętrzenia sztormowe.

Od lat problemem na tym obszarze jest zachowanie bezpieczeństwa dla siedzib ludzkich położonych przy krawędzi klifu, narażonych na zniszczenie przez abrazję. Największe zniszczenia infrastruktury notowano dotychczas w Rewalu (i przyległym Śliwnie), gdzie w ciągu 100 lat erozja wyniosła od 100 do $250 \mathrm{~m}$. Najbardziej wymownym symbolem erozji morskiej i cofania nadbrzeży morenowych południowego Bałtyku jest historia niszczenia kościoła w Trzęsaczu (położony na $373 \mathrm{~km}$ wg kilometrażu wybrzeża). W ocenie analiz badań archiwalnych ten odcinek wybrzeża zawsze był erozyjny (Hartnack 1926, Szopowski 1961, Bohdziewicz 1963, Subotowicz 1982, Musielak 1995, Zawadzka-Kahlau 1999). $\mathrm{Na}$ odcinku od lat dominuje bilans ujemny osadu na plaży i podbrzeżu oraz erozja klifu (Racinowski i in. 1995, Racinowski 1996a). Poniższa szczegółowa charakterystyka została wykonana dla odcinka wybrzeża klifowego w Trzęsaczu (372,5-373 km).

\section{Uwarunkowania hydro-meteorologiczne}

W zachodniej części polskiego wybrzeża przeważa wiatr z kierunków W i SW. Ten o dużej prędkości (ponad $10 \mathrm{~m} \mathrm{~s}^{-1}$ ) występuje $\mathrm{w}$ okresie jesienno-zimowym i najczęściej przeważa z sektora odmorskiego, z kierunków NW, N i NE. Jego udział roczny na zachodnim wybrzeżu wynosi ok. $10 \%$ i wzrasta w kierunku wschodnim do 15\%. Prawdopodobieństwo wystąpienia $\mathrm{w}$ ciągu roku wiatru bardzo silnego o prędkościach powyżej $15 \mathrm{~m} \mathrm{~s}^{-1}$ wynosi ok. 6\% (Zeidler $i$ in. 1995). Wiatr ten jest elementem układów ciśnień przemieszczających się nad Bałtykiem i odpowiedzialnych za podniesienie poziomu morza oraz rozwój sztormowego falowania wiatrowego na wybrzeżu (Kowalewska-Kalkowska, Kowalewski 2005, Wolski 2017).

Powstawanie falowania zwanego sztormowym spowodowane jest przez długotrwały wiatr o dużych prędkościach, wiejący z sektorów otwartego morza. Spiętrzenie (wezbranie) sztormowe na wybrzeżu Bałtyku jest efektem przejścia frontu i głębokiego niżu. Najwięcej spiętrzeń sztormowych przypada na okres jesienno-zimowy (Zeidler i in. 1995, Łabuz 2012b, Wolski 2017). Większość sztormów na zachodnim wybrzeżu powstaje przy wietrze $z$ kie- runków: północnych - 55\%, północno-zachodnich - $31 \%$ i północno-wschodnich - 14\% (Zeidler i in. 1995). Wraz z rozwojem falowania sztormowego następuje podniesienie poziomu morza o 1-2 m powyżej średniego, w takiej sytuacji woda napływająca na brzeg sięga do wysokości 3-3,5 m n.p.m. (Łabuz 2012b, 2013). Podczas takiego zdarzenia, plaże o wysokości niższej nie chronią zapleczy brzegu przed erozją, skutkiem czego jest cofanie lądu. Największe sztormy o sile $10-12^{\circ} \mathrm{W}$ skali Beauforta skutkują najwyższym podniesieniem poziomu morza i najwyższymi falami, które powstają z sektora NE. Najczęstsze sztormy notuje się z kierunku NW. W ciągu 20 ostatnich lat silne sztormy na polskim wybrzeżu kilkakrotnie niszczyły brzeg Wybrzeża Trzebiatowskiego. W listopadzie 1995 r. spiętrzenie $\mathrm{z}$ poziomem morza do $2 \mathrm{~m}$ powyżej średniego (zarejestrowane w porcie Świnoujście i Dziwnów) poważnie uszkodziło brzeg wybrzeża zachodniego. Rozmyte zostały plaże i wydmy na przyległych mierzejach. W okresie objętym badaniami od 1997 do 2017 r. wystąpił szereg spiętrzeń, w niektórych latach były to 2 a nawet 4 podpiętrzenia w ciągu sezonu, które przekroczyły tzw. stan alarmowy w portach (powyżej 0,7 $\mathrm{m}$ ponad poziom średni). W niektórych latach wystąpiły tylko spiętrzenia $z$ wodą przekraczającą 0,5 m, która jedynie podmywała dolną część plaż. W okresie 2001-2011 stany ostrzegawcze poziomu morza w Świnoujściu najczęściej były przekraczane w sezonach jesienno-zimowych 2001/02 - 15 razy, 2006/07 - 11 razy (Malinowska, Filipiak 2013). Sztormy najbardziej niszczące klify badanego odcinka od 1997 r. wystąpiły w: 2002, 2006, 2007, 2009, 2012, 2016, 2017.

Bardzo ważnym czynnikiem warunkującym zmiany morfologiczne klifu są opady (Kostrzewski, Zwoliński 1988). Opady przekraczające $40-50 \mathrm{~mm}$ na dzień skutkują rozwojem osuwisk na klifach (Winowski 2015). Liczba dni z opadem ekstremalnym za okres 2001-2011 wykazuje dużą zmienność (Malinowska, Filipiak 2013). W tym okresie najmniej dni ze znacznym opadem wystąiło w latach 2004, 2005 i 2006. Najwięcej dni z opadem $>20 \mathrm{~mm}$ na dzień, uznawanym za ekstremalny zanotowano na wybrze$\dot{z} u$ zachodnim w porze letniej 2002, 2007 i 2011 r. (Malinowska, Filipiak 2013, Winowski 2015). Wody opadowe zasilają poziomy wód gruntowych, które są jednym z ważniejszych czynników morfodynamicznych (Kostrzewski, Zwoliński 1988, 1995). Tajenie pokrywy śniegu może również prowadzić do uplastycznienia warstw klifu, a tym samym powstawania osuwisk, tak jak stwierdzono to na klifach wyspy Wolin (Winowski 2008). Niski i stromy klif Wybrzeża Trzebiatowskiego nie jest $\mathrm{w}$ stanie zgromadzić pokrywy śnieżnej, która podczas topnienia mogłaby destabilizować jego podłoże. Ten czynnik w interpretacji pominięto. 
W okresie jesienno-zimowym podnóże klifu może być niszczone przez nasunięcia kier lodowych na niski brzeg (Girjatowicz 1999). Liczba dni i rodzaj powstających zjawisk lodowych na polskim wybrzeżu jest znacznie zróżnicowany. Najczęściej pokrywa lodowa powstaje $\mathrm{w}$ płytkich zatokach i przy ujściach rzek. W okresie 2001-2011 do rozwoju pokryw lodowych dochodziło także na wybrzeżu otwartego morza. W okresie zimowym 2009/10 lód na wodach przybrzeżnych występował przez 40 dni, w 2010/11 - 15 dni i w 2011/12 - 12 dni (Malinowska, Filipiak 2013). Nasunięcia lodu na plaże i do podnóża klifu zaobserwowano w sezonie 2002/03, 2009/10 i 2010/11. Z jednej strony pokrywa i kry lodowe chronią brzeg przed falowaniem, jednak nasuwane na ląd zdzierają powierzchnię plaży i podnóże klifu.

\section{Uwarunkowanie geologiczne nadbrzeży morenowych}

Wybrzeże klifowe rejonu Trzęsacza zbudowane jest $z$ dwudzielnych glin zwałowych, moreny dennej ostatniego zlodowacenia (Kopczyńska-Lamparska 1974, Subotowicz 1982, Dobracka, Ruszała 1988, Dobracka, Dobracki 1995, Tomczak 1995). Starsze pochodzą ze zlodowacenia warty, młodsze przyporządkowano do górnego stadiału zlodowacenia wisły (Dobracka, Ruszała 1988, Dobracki, Racinowski 1989, Dobracki 1999). Gliny te na poziomie ok. 0-2,5 m n.p.m. są rozdzielone przez żwiry i piaski. W górnej części ok. 1,5 m od wierzchowiny klifu występują również niewielkie przewarstwienia żwirów (Subotowicz 1982), które są czynnikiem destabilizacji ściany klifu. Po znacznych opadach deszczu, ta przepuszczalna warstwa powoduje powstawanie licznych wysięków wód gruntowych na ścianie klifu. Wydajność wysięków obliczono na $2-50 \mathrm{dm}^{3}$ wody okresowo na minutę (Dobracki 1995). Wody gruntowe wpływają na uplastycznienie gruntu i powstawanie źródeł na klifie. Ich efektem są powstające rozpadliny i nisze warunkujące powolne cofanie ściany klifu.

Według klasyfikacji Subotowicza (1982) pomiędzy Niechorzem a Trzęsaczem występuje typ klifu obrywowego. Wśród ruchów masowych dominują obrywy, a lokalnie występują spływy i zsuwy (Subotowicz (1982), Dobracki (1995, 1999) i Rotnicki (1995). W samym Trzęsaczu, na ścianie klifu przeważają ruchy masowe typu obrywowego i osuwiskowo-spływowego (Subotowicz 1982). Potwierdzają to obserwacje po spiętrzeniach sztormowych z 2002, 2004, 2007 i 2009, kiedy obrywy z podciętych ścian klifów przeważały nad innymi formami ruchów masowych. Na odcinku klifu osłoniętym opaską obecne są tylko lokalne spływy gliny z krawędzi. Glina budująca krawędź jest rozpuszczana po intensywnych opadach deszczu. W ten sposób górna część klifu cofa się w wyniku rozwoju nisz i spływu jęzorów gliny do podnóża.

Według szczegółowych badań geologicznych klif ten ma skomplikowaną strukturę ułożenia warstw, w tym przewarstwienia piasków i iłów, które wpływają na przepuszczalność i rozwój ruchów masowych (Dobracka, Ruszała 1988, Racinowski i in. 1995). Lokalnie ponad glinami występują osady glacifluwialne i glacilimniczne, a całość osadów plejstoceńskich pokrywają osady eoliczne. W głębszym podłożu na starszej glinie także znajdują się przewarstwienia piasków fluwioglacjalnych i zastoiskowych (Dobracka, Ruszała 1988). Pomiędzy glinami stwierdzono warstwy wodonośne, które potencjalnie wpływają na stabilność podłoża nadbrzeży morenowych (Racinowski 1990, Racinowski i in. 1996). Wszystkie te cechy wpływają na stabilność klifu i jego mniejszą odporność na niszczenie.

\section{Morfodynamika brzegu}

$\mathrm{Na}$ omawianym odcinku wybrzeża występuje strefa intensywnego rozmywania podbrzeża i plaży (Dubrawski, Zawadzka-Kahlau 2006). Wały rewowe są niewielkie i sukcesywnie rozmywane lub ulegają przesunięciu $\mathrm{w}$ kierunku morza (Dubrawski, Zawadzka-Kahlau 2006). Badania nad litodynamiką wskazują na dużą średnicę osadu w podbrzeżu i jego słabe wysortowanie oraz częste usuwanie w głąb morza z powierzchni glin plejstoceńskich (Racinowski 1996a). Potwierdzają to przekroje batymetryczne z Trzęsacza sporządzone na zlecenie Urzędu Morskiego w okresach: 2004, 2009 i 2012 r., wykazujące m.in. przenoszenie osadu z płytkiego podbrzeża do stref głębokowodnych (Boniecka 2013).

Odcinek Wybrzeża Trzebiatowskiego cechuje tzw. depozycja okresowa (Racinowski, Seul 1996). W okolicach miejscowości Pustkowo, Pobierowo i Łukęcin na warstwie glin tworzących klif znajdują się piaski eoliczne, które po erozji zasilają szerszą w tym miejscu plażę oraz decydują o powstaniu niskich wydm wałowych i embrionalnych przed morenowym klifem (Musielak i in. 2005). Piaszczyste plaże w okolicy Pobierowa mają szerokość do $45 \mathrm{~m}$. Na tym odcinku wybrzeża przeważa klif martwy. Brzeg na odcinku Trzęsacz-Niechorze zbudowany jest $z$ wychodni glin tworzących platformę abrazyjną, okresowo pokrytą cienką warstwą piasku plaży. Plaże na odcinku Trzęsacz-Rewal-Niechorze są zazwyczaj wąskie i pokryte odsypami żwirowymi. Podczas spiętrzeń sztormowych ten luźny osad jest usuwany, a gliny erodowane. Po opadach lub roztopach spływy gliny z klifu nakładają się na cienką warstwę piasku plaży. Osad pochodzący z erozji klifu cechuje drobna frakcja ilasta, która jest szybko rozmywana i nie zasila plaż. Od kilku lat plaże w tych miejscowościach są sztucznie odtwarzane osadem wybieranym z podbrzeża (refulacja plaż). 
Przed refulacją zapoczątkowaną w 2011 r. szerokość naturalnych plaż w Trzęsaczu nie przekraczała $25 \mathrm{~m}$, a jej wysokość u podnóża wynosiła do $2 \mathrm{~m}$ wysokości bezwzględnej. Po okresach spiętrzeń sztormowych plaża zazwyczaj była rozmyta, płaska i sięgała wysokości $1 \mathrm{~m}$ n.p.m. W okresach pozbawionych spiętrzeń sztormowych sezonowe zmiany wysokości plaży wynosiły $0,3-0,6 \mathrm{~m} \mathrm{w}$ wyniku oddziaływania procesów eolicznych. Po wykonanej refulacji plaża była wyższa i szersza; jej wysokość sięgała $3 \mathrm{~m}$ n.p.m. i chroniła podnóże klifu przed abrazją. Zazwyczaj po 2-3 latach od refulacji osad z plaży był stopniowo usuwany $\mathrm{w}$ wyniku oddziaływania spiętrzeń sztormowych.

Morfodynamika brzegu - zmiany wysokości i szerokości plaż oraz zmiany batymetryczne są głównym czynnikiem obserwowanej geodynamiki nadbrzeża klifowego. W ostatnich latach zwiększała się sukcesywnie liczba spiętrzeń sztormowych $z$ poziomem morza $1 \mathrm{~m}$ ponad średni. W ciągu opisywanych 20 lat wystąpiło szereg gwałtownych zjawisk ekstremalnych: 1995, 2002, 2006, 2007, 2009, 2012, 2013, 2015 , 2017. Skutkowały one zmniejszaniem odporności brzegu, zwężaniem plaż i cofaniem linii brzegowej.

\section{Zabiegi ochrony brzegu na badanym odcinku w okresie 1997-2017}

Zdaniem Subotowicza (1995) budowa opasek powoduje powstawanie umocnionych przyczółków, a pomiędzy nimi brzeg i tak będzie się cofał. Pierwszy, współczesny zabieg ochronny zastosowany w celu zatrzymania erozji i uniknięcia zawalenia ostatniej ściany ruin gotyckiego kościoła to piramidki kardzisa i tetrapody, posadowione na plaży u podnóża ściany klifu w 1986/7 r. W latach 2001-2004 posadowiono u podnóża ściankę Larsena i gabiony na całej wysokości klifu. Przed wykonaniem tego zabiegu usunięto spod klifu całe koluwium. W sąsiedztwie tej konstrukcji, po obu jej stronach klif był nadal aktywny. W jego górnej części powstawały niewielkie obrywy oraz spływy na osi szczelin z wysiękami.

Zmiany erozyjne po sztormach z 2006 i 2007 r. prawdopodobnie były przyczyną podjęcia przez Urząd Morski w Szczecinie działań polegających na zaplanowaniu opaski z głazów pod całym klifem na odcinku Niechorze-Trzęsacz. Zgodnie z programem ochrony brzegów z 2003 r. miano wykonać zabezpieczenie przed sztormem 100-letnim, poprzez budowę opaski, odbudowę plaż o wysokości minimum $2 \mathrm{~m}$ n.p.m. oraz refulację płytkiego podbrzeża $\mathrm{w}$ rejonach o dużej erozji dna. Istnieje jednak ważniejszy powód zastosowania opaski. Ten odcinek wybrzeża należy do gminy Rewal, która spełnia funkcje rekreacyjne i wypoczynkowe, bazujące na pasie plażowym. Utrzymanie odpowiedniej szerokości plaż zwiększa potencjalnie liczbę turystów i generowane dochody dla gminy. Pas lądu przy krawędzi klifu jest gęsto zabudowany, stąd potencjalne straty wynikłe $z$ erozji klifu byłyby znaczne. W latach 2007-2011 wybudowano opaskę pomiędzy Rewalem a Pustkowem o łącznej długości ponad $3 \mathrm{~km}$ od 369,75 do 373,70 $\mathrm{km}$ według kilometrażu linii brzegowej. Ponadto w latach 2013-2014 wykonano opaskę pomiędzy Niechorzem i Rewalem na odcinku 368,2 km do ok. $370 \mathrm{~km}$. Poszczególne jej odcinki wykonano w różnych terminach. Rozciągnięcie budowy w czasie było podyktowane ograniczonym budżetem, pozyskiwaniem funduszy unijnych $z$ programu Infrastruktura i Środowisko ale także ograniczeniami sprzętowo-logistycznymi. Opaska składa się z kilku warstw ułożonych pod odpowiednim kątem: piasku, pospółki, geowłókniny, żwiru i kamieni łamanych o wadze od 300 do $600 \mathrm{~kg}$. Jej wysokość na koronie wynosi ok. 4,2 m n.p.m. Zakrywa całe podnóże klifu, uniemożliwiając jego podmywanie przez morze. Opaski nie zbudowano na odcinkach: portu rybackiego w Rewalu, osłony z tetrapodów pod klifem w Rewalu z 1996 r., u podnóża ruiny kościoła osłoniętej gabionami, w miejscu stanowiska geologicznego osadów jeziornych $\mathrm{w}$ ścianie klifu na $369,7 \mathrm{~km}$ oraz pomiędzy $372,6-372,8 \mathrm{~km}$, gdzie w ścianie klifu gniazdują jaskółki, a odcinek jest włączony do obszaru Natura 2000 (klif pomiędzy Trzęsaczem a przystanią Niechorzu $\mathrm{z}$ wyłączeniem terenu miejscowości wyznaczony jest obszar ochrony Natura 2000 o nazwie Pas Trzebiatowsko-Kołobrzeski (PLH 320010)).

Na wysokości Trzęsacza ta nowa opaska z głazów, łącząca się z dwóch stron ze ścianką szczelną była gotowa już pod koniec 2010 r. Po usunięciu koluwium obłożono nią podnóże klifu do wysokości 4,2 m n.p.m. (ryc. 6B). W górnej części klif był odkryty, pozbawiony roślinności i potencjalnie mógł ulegać erozji. Do maja 2014 r. część opaski przykryła spływająca ze stoku glina. Częściowo przysypał ją też piasek zwiany z refulatu. Opaska jest wspomagana sztucznym zasilaniem brzegu. W latach 2010-2012 pomiędzy Rewalem a Trzęsaczem wykonano cztery refulacje plaży. Łącznie odłożono $700000 \mathrm{~m}^{3}$ piasku, w tym dwukrotnie w Trzęsaczu: w 2011 odłożono 150000 $\mathrm{m}^{3}$ na odcinku 372,8-373,8 km, a w $2012163000 \mathrm{~m}^{3}$ na odcinku $371,8-372,8 \mathrm{~km}$. W celu powstrzymania erozji refulatu w 2014 r. w Trzęsaczu wykonano ostrogi. Plaże zostały jednak zniszczone podczas spiętrzeń sztormowych w 2015, 2016 i 2017 r.

W grudniu 2017 r. ogłoszono plan najnowszej inwestycji na wybrzeżu w okolicy Trzęsacza, której celem jest budowa opaski na ostatnim, naturalnym odcinku klifu. Opaska ta będzie budowana pomiędzy 372,6 a $372,8 \mathrm{~km}$, gdzie powstały nowe, rozległe osuwiska po sztormach $z$ sezonu jesienno-zimowego 2016/17. W ten sposób zniknie ostatni naturalny odcinek klifu, pomimo jego położenia na obszarze Natura 2000. 


\section{Zmiany morfodynamiczne klifu w Trzęsaczu}

\section{Historyczne zmiany położenia klifu}

Zmiany historyczne związane $z$ erozją klifu i niszczeniem kościoła zawiera tabela 1. Kościół murowany w Trzęsaczu powstał na przełomie XIV/XV w. na miejscu drewnianego z XIII w. (1270 r.). Kościół drewniany po wybudowaniu znajdował się podobno ok. 1,8 km od krawędzi klifu, przed nim położony był cmentarz i rozmieszone były domy osady Trzę- sacz. Dobracki (1999) podaje, że w okresie 500 lat od zbudowania kościoła klif cofał się o 3,6 $\mathrm{m} \mathrm{a}^{-1}$, danych tych jednak nie można obecnie zweryfikować. Zapis historyczny cofania klifu $\mathrm{w}$ tym okresie zawiera tabela 1. W 1750 r. kościół stał ok. 58 m od krawędzi klifu. W 1820 r. było to już ok. 12 m od krawędzi klifu. Erozję próbowano powstrzymać usypując u podnóża klifu głazy wypłukane uprzednio z moreny. W 1870 r. kościół był już tylko $5 \mathrm{~m}$ od krawędzi klifu. W 1872 r. na wybrzeżu Bałtyku południowego zarejestrowano najsilniejszy sztorm $z$ najwyższym kiedykolwiek poziomem morza (także do dzisiaj) - w Kołobrzegu woda sięga 2,22 $\mathrm{m}$ nad poziom średni. W 1874

Tabela 1. Najważniejsze historyczne zjawiska związane z erozją klifu w Trzęsaczu do 1997 (opracowanie własne na podstawie publikacji, fotografii i map)

Table 1. Main historical phenomenon related to cliff erosion in Trzęsacz till 1997 (own preparation based on publications, photographs and maps)

\begin{tabular}{|c|c|c|c|}
\hline $\begin{array}{l}\text { Okres } \\
\text { Period }\end{array}$ & $\begin{array}{l}\text { Rok } \\
\text { Year }\end{array}$ & $\begin{array}{l}\text { Tempo erozji } \\
\text { roczne } \\
\text { Rate of erosion } \\
{\left[\mathrm{m} \mathrm{a}^{-1}\right]}\end{array}$ & $\begin{array}{l}\text { Odległość kościoła od krawędzi [m] } \\
\text { Procesy kształtujące klif w sąsiedztwie } \\
\text { Church distance from cliff Edge [m] } \\
\text { Processes that shape cliff near church ruin }\end{array}$ \\
\hline $\begin{array}{c}1270- \\
1870\end{array}$ & $\mathrm{nn}$ & Ok. 0,33 & $\begin{array}{l}\text { Zbudowany } \mathrm{w} \text { XV w na miejscu drewnianego z XIII w (1270), prawdopodobnie } \\
\text { położnego ok } 1,8 \mathrm{~km} \text { od morza, czyli byłoby to tempo cofania } 0,33 \mathrm{~m} \mathrm{a}^{-1} \text {, w okresie } \\
600 \text { lat }\end{array}$ \\
\hline \multirow[t]{8}{*}{$\begin{array}{l}1750- \\
1874\end{array}$} & 1750 & 0,58 & $\begin{array}{l}\text { Odległość } 58 \mathrm{~m} \text {. Pierwsze próby zabezpieczenia klifu. Erozja obliczona na } \\
\text { podstawie odległości kościoła od krawędzi }\end{array}$ \\
\hline & 1782 & 0,70 & $\begin{array}{l}\text { Największy zarejestrowany sztorm z poziomem wody } 2,2 \mathrm{~m} \text { nad średni znacznie } \\
\text { eroduje klif, powstają obawy o przyszłość kościoła }\end{array}$ \\
\hline & 1806 & 0,50 & Odległość 15 m \\
\hline & 1820 & 0,16 & Odległość 13 m \\
\hline & 1828 & 0,12 & $\begin{array}{l}\text { Po sztormie zniszczenie dzwonnicy, pękające ściany. Kolejne próby zabezpieczenia } \\
\text { klifu. W } 1835 \text { r. odległość niecałe } 12 \mathrm{~m}\end{array}$ \\
\hline & 1855 & 0,44 & Odległość 5 m \\
\hline & 1868 & 0,30 & Odległość $1 \mathrm{~m}$ od 1868 do około 1874 \\
\hline & 1874 & 0,15 & Zamknięcie kościoła, brak wzmianek o erozji do 1890 \\
\hline \multirow{6}{*}{$\begin{array}{c}1875- \\
1930\end{array}$} & Od 1875 & 0,40 & Erozja za okres 1875-1983 obliczona na podstawie map (Zawadzka-Kahlau 1999) \\
\hline & $1880 / 91$ & 0,10 & $\begin{array}{l}\text { Odległość } 0 \text { m. Budynek cały stoi na krawędzi klifu. Klif aktywny, bez roślinności. } \\
\text { W } 1887 \text { jest już bez dachu. W } 1891 \text { osunięcia ziemi spod kamiennych } \\
\text { fundamentów w części zachodniej }\end{array}$ \\
\hline & $1900 / 13$ & 0,30 & $\begin{array}{l}\text { W } 1900 \text { odpada pierwszy fragment podpory muru. W } 1901 \text { po sztormie zawala } \\
\text { się wraz z klifem ściana północna. W kolejnych latach odpadają następne części } \\
\text { murów. Erozja około } 4 \text { m. Klif cały czas jest aktywny }\end{array}$ \\
\hline & 1914 & 0,50 & Osunięcia po sztormie z 1914 - poziom morza 2 m powyżej średniego \\
\hline & $1914 / 20$ & 0,23 & Dalsze odpadanie fragmentów ścian szczytowych \\
\hline & $1920 / 35$ & 0,10 & W dolnej części klifu okresowa stabilizacja - pojawia się roślinność \\
\hline \multirow{4}{*}{$\begin{array}{l}1930- \\
1995 \\
(1997)\end{array}$} & $1960 / 72$ & 0,60 & $\begin{array}{l}\text { Klif częściowo stabilny. Do roku } 1972 \text { podnóże stabilne, w części zach. krzewy na } \\
\text { stoku }\end{array}$ \\
\hline & $1972 / 80$ & 0,20 & $\begin{array}{l}\text { Po sztormach osuwanie klifu, skutkuje dalszym odpadaniem fragmentów muru. } \\
\text { Erozja obliczona na około } 0,20 \mathrm{~m} \mathrm{a}^{-1}\end{array}$ \\
\hline & $1983 / 94$ & 0,30 & $\begin{array}{l}\text { W tym czasie klif stabilizuje się, porośnięty krzewami rokitnika. W górnej, części } \\
\text { przy krawędzi osuwiska. W } 1994 \text { zawala się część ostatniej ściany południowej, po } \\
\text { sztormach z grudnia } 1993\end{array}$ \\
\hline & $1995 / 97$ & 0,15 & $\begin{array}{l}\text { Po dużym spiętrzeniu sztormowym z poziomem morza ponad } 2 \text { m nad średni } \\
\text { erozja całej ściany klifu. Liczne obrywy, usunięcie roślinności ze ściany na wschód } \\
\text { od ruin }\end{array}$ \\
\hline
\end{tabular}


r. odbyło się ostatnie nabożeństwo i kościół został zamknięty. Fotografia opuszczonego kościoła z 1880 r. jeszcze ukazuje cały obiekt stojący na samej krawędzi aktywnego klifu, a już 1887 r. obiekt nie posiadał dachu (ryc. 5). W 1891 r. odsłonięte zostały fundamenty jego zachodniej części. Początek niszczenia kościoła na krawędzi cofającego się klifu przypada na marzec 1900 r. Do 1905(7) r. cała północna ściana wraz z klifem została zniszczona przez spiętrzenia sztormowe. Ściana klifu była odkryta, a plaża nisko położona nad poziom morza i wąska. Stan taki występował do ok. 1914 r. W grudniu 1914 r. na wybrzeżu Bałtyku południowego zanotowano drugi co do podpiętrzenia wody sztorm od czasu rozpoczęcia rejestracji poziomu morza (w Kołobrzegu woda sięgała $2 \mathrm{~m}$ nad poziom średni). Cofnięcie krawędzi klifu po-
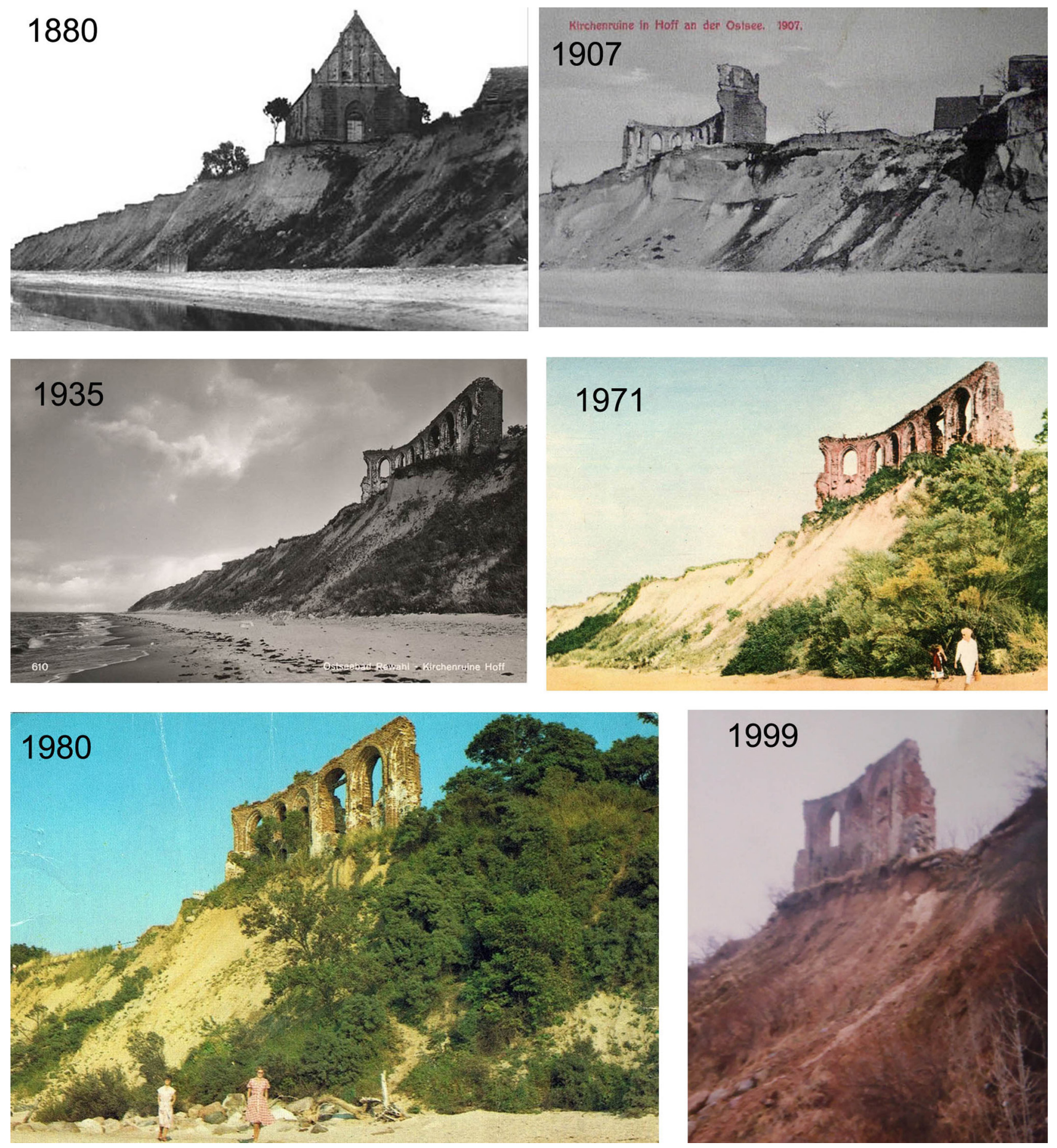

Ryc. 5. Niszczenie kościoła i klifu w Trzęsaczu na podstawie historycznych fotografii (Internet dostęp 12.2017, fot. T.A.Łabuz 1999)

Fig. 5. History of cliff and church erosion based on old photographs (Internet, 12.2017, photo T.A.Łabuz 1999) 
między 1907 a 1914 r. wyniosło ok. 4 m. Dokumentację opisową i fotograficzną z tego okresu prezentuje praca Hartnacka (1926). Do ok. 1925 r. erozja krawędzi wyniosła ok. 1-1,5 m. W tym czasie odpadały kolejno fragmenty ścian ruiny: wschodniej i zachodniej. Do ok. 1930(5) r. południowa ściana ruin znajdowała się ok. 7-8 m od krawędzi, a erozja klifu wyniosła ok. $2 \mathrm{~m}$. W latach 30. XX w. klif był częściowo nieaktywny. Po roku 1935 podnóże klifu było gęsto porośnięte krzewami rokitnika. Górna cześć ściany nosiła znamiona licznych i częstych spływów gliny. W latach 40. XX w., do końca wojny Niemcy wykonali w samym Rewalu krótki odcinek opaski betonowej chroniącej budynki na krawędzi klifu oraz szereg ostróg, co wynikało z postępującej erozji i obsuwania budynków w miejscowości.

Według analizy zdjęć lotniczych z okresu 19511973 podstawa klifu na zachód od ruiny kościoła cofnęła się o 2-4 m, a na odcinku położonym na wschód, w kierunku Rewala cofnięcie dochodziło do 10 m (Dudzińska-Nowak, Furmańczyk 2005). Od lat 40. do lat 60. XX w. klif bezpośrednio sąsiadujący $z$ ruiną kościoła cofnął się o ok. $2-3 \mathrm{~m}$. W połowie lat 60. XX w. klif w okolicy Trzęsacza był częściowo aktywny. W latach 70. i 80. XX w. część podnóża klifu najczęściej była nieaktywna, pokryta przez roślinność. Ostatnia, południowa ściana ruiny kościoła stała ok. $5 \mathrm{~m}$ od samej krawędzi klifu. Stan taki trwał do ok. 1976 r. W styczniu 1976 r. wystąpiło znaczne spiętrzenie $z$ poziomem wody $1,28 \mathrm{~m}$ ponad średni, a w 1978 r. z poziomem wody $1 \mathrm{~m}$ ponad średni (poziomy zarejestrowane w Kolobrzegu). Po tych spiętrzeniach odcinek na wschód od ruiny stał się klifem aktywnym. Na całej wysokości ściany aktywne były ruchy masowe. Na stoku w części zachodniej pozostało część krzewów. Szerokość plaży dochodziła do ok. 25-35 m. Erozja w latach 60. i 70. XX w. wynikała przede wszystkim z ruchów masowych, zachodzących w górnej części ściany klifu. Do lat 90. XX w. cofaniu podlegała aktywna dolna część klifu. W 1990 r. ostania południowa ściana stała ok. $1 \mathrm{~m}$ od krawędzi. W tym czasie u podnóża rozmieszono betonowe gwiazdobloki. W całej górnej części klif miał nachylenie do $80^{\circ} \mathrm{i}$ był aktywny, a w dolnej jego nachylenie wzrastało $z$ zachodu na wschód. Ostatni większy fragment ściany południowej (z dwoma oknami) runął na plażę dnia 1 lutego 1994 r. Było to skutkiem spiętrzenia sztormowego $z$ poziomem morza $0,8 \mathrm{~m}$ ponad średni, które wystąpiło $\mathrm{w}$ dniach 28/29.01.1994 r. Po bardzo silnym spiętrzeniu sztormowym z poziomem morza 2,00 m powyżej średniego $z$ dnia 04.11.1995 r. klif Wybrzeża Trzebiatowskiego cofnął się o 2-3 m. Uszkodzone zostały obiekty zabudowy w Rewalu, a ściana zabytkowego kościoła w Trzęsaczu zagrożona była runięciem. Po tym spiętrzeniu w Rewalu w 1996 r. zbudowano opaskę z gwiazdobloków i zabudowano cały klif w miejscu zagrożonych obiektów infrastruktury. Po kilku latach konstrukcja ta konstrukcja zaczęła osiadać w podłożu. W Trzęsaczu erozja podnóża i osunięcia klifu spowodowały odsłonięcie fundamentu ostatniej ściany ruiny, wtedy powstał plan jej ratowania. Zakładał on kompleksową osłonę ściany klifu oraz stabilizację podłoża i fundamentów za pomocą pali i kotw.

Na podstawie pomiarów kartometrycznych wykonanych na mapach ustalono, że w okresie od 1875 do 1983 r. linia brzegowa Wybrzeża Trzebiatowskiego cofała się średnio ok. 0,9 $\mathrm{m} \mathrm{a}^{-1}$, a cofanie krawędzi klifu dochodziło do 0,4 $\mathrm{m} \mathrm{a}^{-1}$ (Zawadzka-Kahlau 1999). Tempo erozji klifu $\mathrm{w}$ Trzęsaczu $\mathrm{w}$ latach 60. XX w. oszacowano na 0,6-0,8 $\mathrm{m} \mathrm{a}^{-1}$ (Szopowski 1961, Bohdziewicz 1963). Rozpoznanie tempa erozji komplikowały umocnienia, które były w tym czasie wybudowane w Niechorzu i Rewalu (Bohdziewicz 1963). W samym Trzęsaczu roczna erozja lądu w okresie 1875-1979 wynosiła 0,4 $\mathrm{m} \mathrm{a}^{-1}$ (Zawadzka-Kahlau 1999, Dubrawski, Zawadzka-Kahlau 2006). Tempo cofania klifu w okresie 1971-1983 obliczono na $0,6-0,8 \mathrm{~m} \mathrm{a}^{-1}$ (Zawadzka-Kahlau 1999). Od 1951 do 1996 r. klif w tej okolicy cofnął się o 7-11 m (Dudzińska-Nowak, Furmańczyk 2005), co daje około 0,25 $\mathrm{m} \mathrm{a}^{-1}$. Z kolei Dobracki $(1995,1999)$ oszacował erozję klifu w okolicy Trzęsacza aż na 3,6 $\mathrm{m} \mathrm{a}^{-1}$. Należy podkreślić, że w samym Rewalu od 1910 r. do dziś (2017 r.) klif cofnął się od 80 do ponad $120 \mathrm{~m}$, to jest w tempie ok. 0,8 do 1,2 $\mathrm{m} \mathrm{a}^{-1}$. Największe tempo erozji klifu występuje nie $\mathrm{w}$ Trzęsaczu a sąsiednim Rewalu.

\section{Morfodynamika klifu i plaży w latach 1997- 2010, sprzed budowy opaski}

Zapis procesów obserwowanych podczas badań terenowych zawiera tabela 2. Po spiętrzeniu sztormowym $z$ listopada $1995 \mathrm{r}$. klif był aktywny na prawie całym odcinku Pustkowo-Niechorze. Podczas pierwszych obserwacji terenowych przeprowadzonych w lipcu 1997 r. szerokość plaży w okolicach Trzęsacz-Rewal wynosiła 25-30 m. Jej wysokość u podnóża klifu nie przekraczała 1,7 m n.p.m. Na zachód, w kierunku Pustkowa na klifie istniały aktywne osuwiska piasku $z$ warstw położonych ponad krawędzią gliny. W części wschodniej Trzęsacza występowały jęzory spływowe gliny. W styczniu 1999 r. po roztopach powstały rozległe jęzory spływowe glin, sięgające do 4-5 m na plażę. Relatywnie szerokie plaże piaszczyste $z$ lat 1997/99 uległy rozmyciu po cyklu sztormów: kilku z listopada 2001 r. i znacznego ze stycznia 2002 r. z poziomem morza $1,2 \mathrm{~m}$ ponad średni. W wyniku spiętrzeń sztormowych z sezonu jesienno-zimowego 2001/02 podnóże klifu cofnęło się od 0,2 do 0,5 m, a jego krawędź o ok. $0,25 \mathrm{~m}$. W tym czasie odpadł niewielki i ostatni jak dotychczas fragment fundamentu zachodniej części 
Tabela 2. Najważniejsze zjawiska związane z erozją klifu w Trzęsaczu w latach 1997-2017

Table 2. Main phenomenon related to cliff erosion in Trzęsacz in years 1997-2017

\begin{tabular}{|c|c|c|c|}
\hline $\begin{array}{l}\text { Okres } \\
\text { Period }\end{array}$ & $\begin{array}{l}\text { Rok } \\
\text { Year }\end{array}$ & $\begin{array}{l}\text { Tempo erozji } \\
\text { roczne } \\
\text { Rate of erosion } \\
{\left[\mathrm{m} \mathrm{a}^{-1}\right]}\end{array}$ & $\begin{array}{l}\text { Procesy kształtujące klif w sąsiedztwie ruiny kościoła } \\
\text { Processes that shape cliff near church ruin }\end{array}$ \\
\hline \multirow{3}{*}{$\begin{array}{l}1997- \\
2000\end{array}$} & 1997/99 & 0,15 & Klif aktywny, widoczne spływy gliny \\
\hline & 1999 & 0,10 & Wiosenne spływy po roztopach, rozległe jęzory gliny na plaży do jesieni \\
\hline & 2000 & 0,10 & Stabilizacja ściany klifu, niewielkie obrywy \\
\hline \multirow[t]{3}{*}{$\begin{array}{l}2001- \\
2005\end{array}$} & $2001 / 02$ & 0,23 & $\begin{array}{l}\text { Erozja przez sekwencję następujących po sobie sztormów z listopada, spływy po } \\
\text { opadach, jęzory gliny na plaży, koluwium z obrywów }\end{array}$ \\
\hline & $2002 / 03$ & 0,00 & Ukończenie zabudowy ściany pod ruiną kościoła. Stabilizacja tego odcinka \\
\hline & $2004 / 05$ & 0,20 & $\begin{array}{l}\text { Od } 2004 \text { cofanie krawędzi występuje tylko na wschód od ruiny. Erozja przez } \\
\text { spiętrzenie z listopada } 2004\end{array}$ \\
\hline \multirow[t]{3}{*}{$\begin{array}{l}2006- \\
2009\end{array}$} & 2006/07 & 0,36 & $\begin{array}{l}\text { Sekwencja sztormów znacznie eroduje klif, powstają pionowe podcięcia ścian, } \\
\text { koluwium z podnóży usunięte przez falowanie }\end{array}$ \\
\hline & $2007 / 08$ & 0,10 & $\begin{array}{l}\text { W okresie letnim intensywne opady powodują powstanie rozległych spływów } \\
\text { gliny na plaży }\end{array}$ \\
\hline & 2009 & 0,30 & $\begin{array}{l}\text { Erozja dolnej części klifu przez spiętrzenie z października. Rozpoczęcie budowy } \\
\text { opaski w kilku miejscach od Niechorza do Pustkowa. Rozległe nisze na krawędzi }\end{array}$ \\
\hline \multirow[t]{5}{*}{$\begin{array}{l}2009- \\
2017\end{array}$} & $2010 / 12$ & 0,11 & $\begin{array}{l}\text { Tylko niewielkie osuwiska po opadach letnich. Powstają wyraźne zagłębienia - } \\
\text { nisze w linii przebiegu krawędzi o głębokości 0,2 m. Rozmycie refulatu plaży przez } \\
\text { sztormy z } 2012\end{array}$ \\
\hline & 2013 & 0,10 & $\begin{array}{l}\text { Podnóże stabilne, nowa refulacja. Po opadach i przejściu w grudniu huraganu } \\
\text { Xavier, na krawędzi rozwijają się uprzednio powstałe nisze, erozja około } 0,1 \mathrm{~m} \text {. } \\
\text { Powstają nowe nisze }\end{array}$ \\
\hline & $2014 / 15$ & 0,12 & $\begin{array}{l}\text { Formy eoliczne utworzone na opasce z osadu wywianego z refulatu pokrywa } \\
\text { roślinność. Po opadach spływy gliny, erozja w niszach 0,2-0,3 w } 2014 \text { i 0,1-0,4 } \\
\text { w 2015. Rozmycie refulatu przez sztormy ze stycznia } 2015\end{array}$ \\
\hline & $2016 / 17$ & 0,22 & $\begin{array}{l}\text { Jesienią } 2016 \text { sztormy niszczą plażę. W styczniu } 2017 \text { podczas znacznego } \\
\text { spiętrzenia Axel woda rozmywa osad eoliczny i spływowy z opaski oraz podnóża } \\
\text { odsłoniętego klifu. Woda sięga aż } 3,8 \mathrm{~m} \text { npm. Cofniecie krawędzi o około } 0,5 \mathrm{~m} \text {, } \\
\text { a nad opaską do } 0,15 \mathrm{~m} \text {. Ruchy masowe przez całe lato }\end{array}$ \\
\hline & $2017 / 18$ & 0,15 & $\begin{array}{l}\text { Jesienią kolejne dwa spiętrzenia rozmywają plażę i sięgają podnóża klifu w miejscu } \\
\text { bez opaski. Powstały rozległe spływy gliny i cofnięcie krawędzi o około } 0,2 \mathrm{~m}\end{array}$ \\
\hline $2018-$ & Od 2018 & $\mathrm{nn}$ & $\begin{array}{l}\text { Do wiosny brak spiętrzeń. Od } 2018 \text { zaplanowano budowę opaski z głazów na } \\
\text { ostatnim naturalnym odcinku klifu }(372,55-272,8 \mathrm{~km})\end{array}$ \\
\hline
\end{tabular}

pozostałej ściany ruiny kościoła (kamienie z fundamentu i kilkanaście cegieł). Na ścianie klifu we wschodniej części Rewala i w Trzęsaczu powstały rozległe jęzory spływowe, jako efekt opadów deszczu i podcinania podnóża klifu przez napływ na brzeg fal morskich.

W latach 2001/02 zabudowano gabionami dolną, a następnie całą ścianę klifu na wysokości ruiny kościoła. Po obu stronach zabiegu powstały nowe osunięcia klifu. Na sąsiednich, przyległych odcinkach klif pozostał odkryty na całej swej wysokości. Po opadach deszczu z okresu letniego 2002 r. na odkrytej ścianie klifu powstały jęzory spływowe gliny. Plaża miała niewielką wysokość i szerokość. Spiętrzenia z grudnia 2003 r. erodowały jedynie plażę. Po sztormie o nazwie Pia z 23.11.2004 r. z poziomem morza $1 \mathrm{~m}$ powyżej średniego, erozja wystąpiła na wschód Rewala; w Sliwnie uszkodzone zostały fundamenty budynków na klifie, a cofnięcie podstawy klifu po rozmyciu koluwium wynosiło miejscami 2,5 m. Uaktywnione ponownie procesy erozji klifu w Trzęsaczu $z$ powodu podcinania jego podnóża przez spiętrzenia sztormowe z 12.2003 i 11.2004 r. spowodowały rozwój osunięć na ścianach klifu. Jego krawędź cofnęła się o 0,2 do $0,5 \mathrm{~m}$. Nowa opaska w wyniku odbijania fal sztormowych spowodowała na swoich krańcach wzmożenie procesu erozji. Na zakończeniach tej budowli erozja krawędzi była większa i dochodziła do 2 m za okres 2002-2004 r. W górnej części klifu powstały rozległe półkoliste wcięcia, a u podnóża nisze i jęzory spływowe gliny. Jednak już latem 2005 r. u podnóża klifu rozwijały się płaty roślinności pionierskiej, w tym halofity i psammofity. Było to efektem zatrzymania erozji klifu w wyniku powstania rozległego koluwium. Rok 2005 do 2006, to również okres stabilizacji górnej części klifu, co wynikało $z$ wyjątkowo małej ilości opadów rejestrowanych w latach 2004-2006 (Malinowska, Filipiak 2013). 
Spiętrzenie sztormowe Brita z 01.11.2006 r. (poziom morza $1,47 \mathrm{~m}$ nad poziom średni, mierzony w Świnoujściu) i cykl spiętrzeń z wysokim poziomem morza trwający do połowy lutego 2007 r. poważnie naruszyły stabilność całego odcinka klifów Wybrzeża Trzebiatowskiego. Woda podczas spiętrzenia sztormowego Brita sięgała do wysokości 3,6 m n.p.m. $\mathrm{Z}$ podnóży klifu usunięte zostało całe koluwium (powstałe pomiędzy 2004 a 2005 r.). Po tym sztormie w kilku miejscach utworzyły się nisze osuwiskowe o rozmiarach 3 m głębokości i 2-3 m szerokości i wysokości. Powstały liczne obrywy i spękania ścian klifów na całym odcinku od Niechorza do Trzęsacza. Plaże zostały rozmyte zupełnie, aż do wychodni glin na platformie abrazyjnej. W trakcie tego spię- trzenia erozja polegała na odrywaniu fragmentów gliny od ścian aktywnego już klifu, powstały nowe nisze, a stare miejscami zostały pogłębione. Klif był aktywny na całym odcinku pomiędzy Niechorzem a Pustkowem. W wyniku wystąpienia następnych kilku spiętrzeń sztormowych w styczniu 2007 r. klif cofnął się u podnóża o $0,4-0,7 \mathrm{~m}$, a przy krawędzi o ok. 0,45 m. Po sztormie z listopada oraz stycznia, od jego pionowych ścian odrywały się bloki gliny o rozmiarach 2 na $3 \mathrm{~m}$. W wyniku erozji usunięta została cała roślinność, która do tej pory wkraczała na ustabilizowane koluwium i ścianę klifu. Obserwacje z lutego 2007 r. wykazały, że na całym odcinku wybrzeża Niechorze-Pustkowo klif był aktywny, plaża została zupełnie rozmyta i obniżona u jego pod-
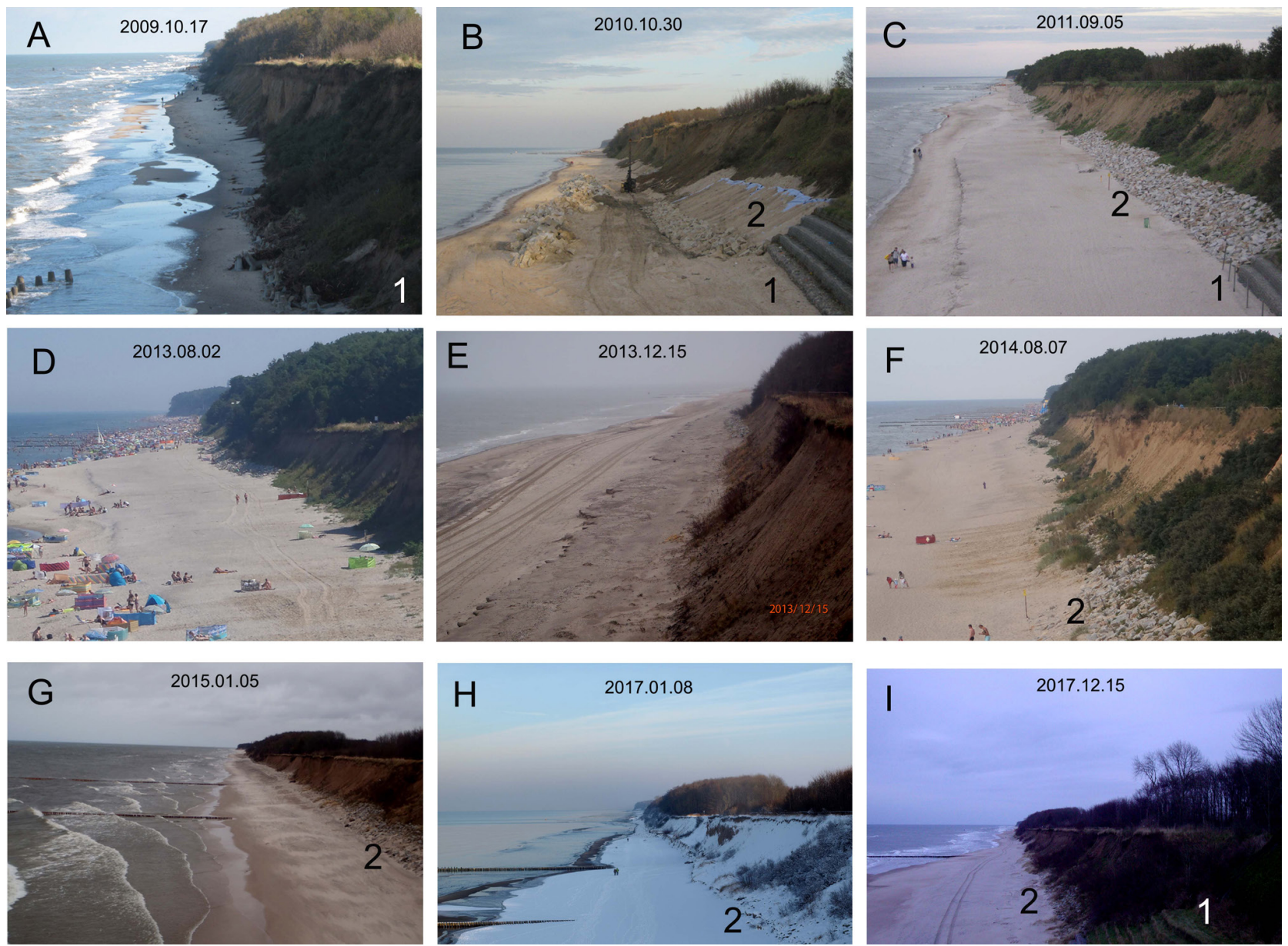

Ryc. 6. Geodynamika klifu i plaży w Trzęsaczu

1 - opaska z gabionów pod ruiną kościoła od 2002, 2 - opaska z głazów od 2010, A - 2009, wąska plaża i podcięty klif dwa dni po sztormie, B - 2010, budowa opaski z głazów pod klifem, C - 2011, plaża po pierwszej refulacji, D - 2013, plaża po drugiej refulacji, pod klifem formy akumulacji eolicznej, E - 2013 grudzień, po sztormie Xavier rozmyta $1 \frac{1}{2}$ refulatu plaży, aktywna górna część klifu, F - 2014, wiosenne spływy gliny na plażę, G - 2015 styczeń, rozmyta plaża, transport eoliczny podczas sztormu Felix, H - 2017 styczeń, obniżona plaża i 1,5 m wysokości podcięcia klifu tuż po sztormie Axel, I - 2017 grudzień, niska plaża i nowe podcięcia oraz spływy na klifie po sztormie Grzegorz

Fig. 6. Cliff and beach geodynamic in Trzęsacz

1 - gabion's band at the cliff foot with church ruin, since 2002, 2 - boulder's band since 2010, A - 2009, narrow beach and cut off cliff two days after storm surge, B - 2010, construction of boulder's band, C - 2011, beach after first ever nourishment, D - 2013, beach after $2^{\text {nd }}$ nourishment, at the foot aeolian accumulation, E - 2013 December, $1 / 2$ of eroded beach after storm Xavier, active upper part of cliff, F - 2014, spring clay slides on beach, G - 2015 January, eroded beach and aeolian transport during surge Felix, H - 2017 January, lowered beach and 1,5 m high cliff cutoff after surge Axel, I- 2017 December, low beach and new cliff cut off an larger slides after surge Gregory 

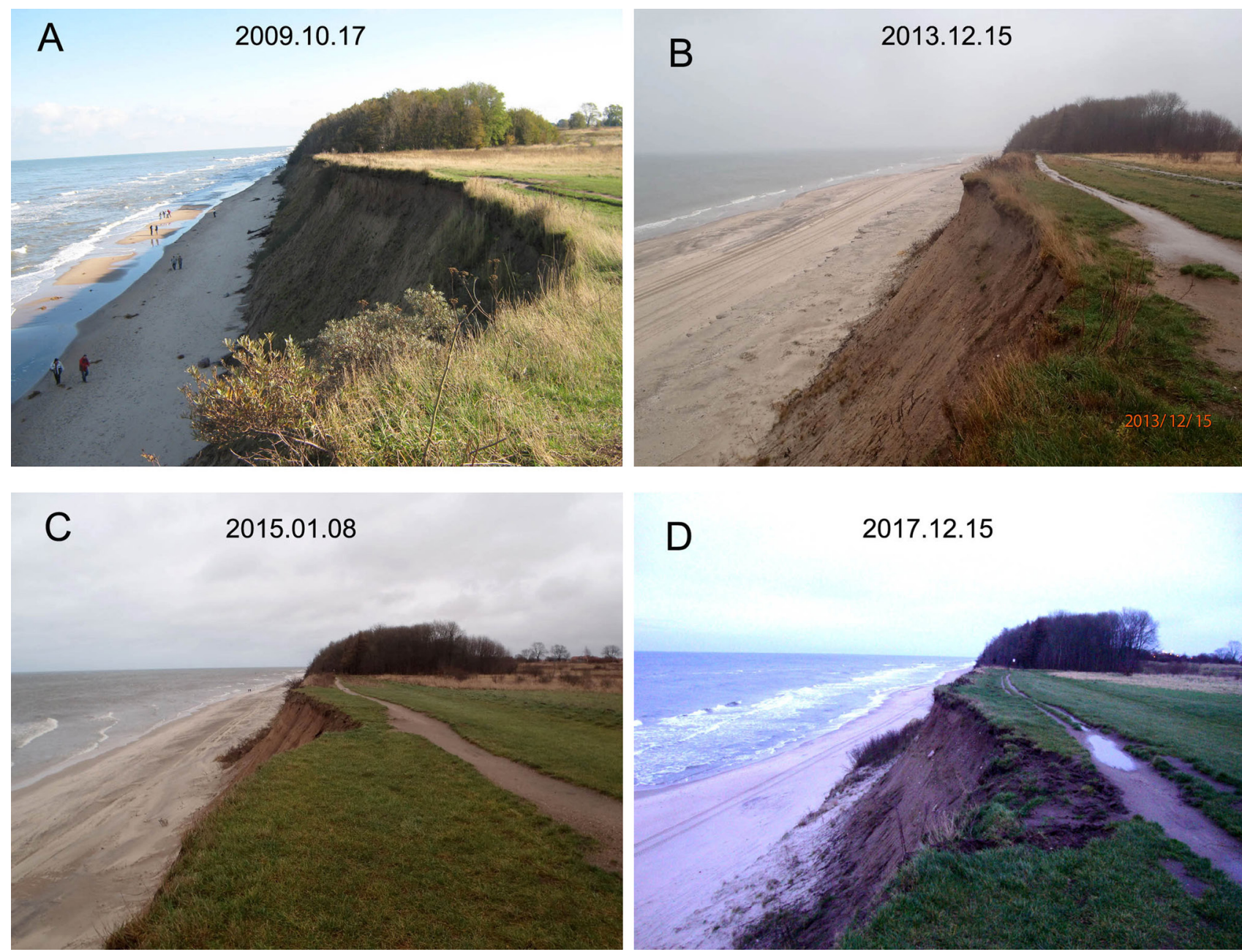

Ryc. 7. Rozwój nisz na krawędzi klifu po spiętrzeniach sztormowych $(372,8$ km)

A - nisze po sztormie z 14/15.10.2009, B - wyrównany klif po sztormach Andrea z 05 i 14.01.2012 i Xavier z 05.12.2013, C - rozwój nisz po sztormie Felix z 05.01.2015, D - znaczne osunięcie po spiętrzeniach Axel z 05.01.2017 i Grzegorz z 30.10.2017

Fig. 7. Development of niches on cliff edge after storm surges $(372.8 \mathrm{~km})$

A - niches after storm surge of 14/15.10.2009, B - aligned cliff after storm surges Andrea from 05 and 14.01.2012 and Xavier from 05.12.2013, C - development of niches after storm Felix from 05.01.2015, D - larger landslide after surges Axel from 05.01.2017 and Gregory from 30.10.2017

nóża do wysokości 1,5 m n.p.m. Pozostałość plaży tworzyły odsypy żwirowe bezpośrednio odłożone na platformie abrazyjnej. Łącznie, w okresie 2002-2007 klif względem odcinka osłoniętego opaską z gabionów cofnął się o 2-3 m. Po tych ekstremalnych zjawiskach Urząd Morski w Szczecinie, odpowiedzialny za powstrzymanie erozji nadbrzeży i brzegu, postanowił powstrzymać cofanie klifu na całym odcinku Niechorze-Trzęsacz. Kolejne spiętrzenie sztormowe doprowadziłoby do zawalenia ścian licznych ośrodków i domów na klifie w Rewalu i Śliwnie. W lipcu 2007 r. na wybrzeżu zachodnim zanotowano znaczne opady deszczu (Winowski 2015). W wyniku tych opadów na klifie powstały nowe jęzory spływowe. Dolna część pionowego uprzednio klifu została pokryta spływami gliny. W górnej części cofnięcie krawędzi w wyniku nasiąknięcia i spływania warstw gliny sięgało 0,1 m. Niewielki sztorm z 27.09.2007 r. z poziomem morza $0,8 \mathrm{~m}$ powyżej średniego spowodował rozmycie częściowo odbudowanej plaży. Podnóże klifu nie było w tym czasie niszczone. Od 2007 do 2008 r. nie występowały spiętrzenia sztormowe, które mogły erodować podnóże klifu (03.2008 r. podczas spiętrzenia, tylko dolna część plaży została rozmyta). W okresie kwietnia 2008 r. opady deszczu ponownie powodowały spływy gliny ze stoku odkrytego klifu. Wielkość opadów na zachodnim wybrzeżu była wtedy znaczna, przekraczając sumy średnie dla tego miesiąca (Winowski 2015).

Od 2009 r. podnóże klifu na Wybrzeżu Trzebiatowskim w wielu miejscach było już osłonięte opaską z narzutu głazów. W Trzęsaczu, do jesieni 2009 r. na ścianie klifu nie obserwowano zmian morfologicznych. Plaże były nadal, jak przez ostatnie lata, wąskie do 20-25 m szerokości i wysokości rzędu 1,8 m n.p.m. W dniach 14-16.10.2009 r. silne spiętrzenie 
sztormowe, rozwijające się z kierunku północnego spowodowało rozmycie wąskich plaż i podcinanie nieosłoniętych opaską podnóży klifu na całym odcinku od Niechorza do Pustkowa (ryc. 6). Na podstawie obserwacji dokonanych tuż po sztormie dnia 17.10.2009 r. w Trzęsaczu i na wschód od ścianki z gabionów stwierdzono zanik plaż i erozję podnóży klifu. W wyniku podcięcia klifu powstały obrywy gliny $z$ krawędzi i stoku klifu. W oparciu o zestawienie położenia krawędzi i podnóża klifu na wschód od ruiny kościoła w okresie 2007 i 2009 ustalono, że cofnięcie podnóża klifu wyniosło ok. 0,3 m a krawędzi 0,3 do 0,7 m. Na wyrównanej dotychczas ścianie powstało kilka nowych nisz (ryc. 6A, 7A). W okresie 2008 do 2009 r. przy ruinie powstał nowy taras widokowy.

W 2010 r. rozpoczęto budowę opaski z narzutu głazów na wschód i na zachód od ściany $z$ gabionów (ryc. 6B). Zabieg ten miał powstrzymać dalszą erozję podnóża klifu w sąsiedztwie ścianki z gabionów. W sumie od roku 2000 do rozpoczęcia budowy opaski w 2010 r. erozja krawędzi klifu na odcinku do $200 \mathrm{~m}$ na wschód od ruiny kościoła wyniosła od 4 do $6,5 \mathrm{~m}$, tj. do około $0,8 \mathrm{~m}$ rocznie. W miejscu lokalizacji ruiny kościoła erozję podnóża oraz ściany górnej powstrzymała zbudowana do 2002 r. opaska z gabionów. Po zabudowaniu klifu opaską z głazów rozpoczęto także wykonywanie refulacji plaż.

\section{Morfodynamika klifu i plaży w latach 2010- 2017, po zabudowaniu podnóża klifu opaską}

Spiętrzenie sztormowe, które na zachodnim wybrzeżu Polski powstało w okresie 14/15.12.2010 r. spowodowało jedynie rozmywanie wąskich plaż u podnóża klifu. Od stycznia 2011 r. plaże pokrywały rozległe kry lodowe, piętrzące się do wysokości 2 m n.p.m. Do wiosny roku 2011 klif był zamarznięty, a lód na plaży występował aż do końca lutego. W okresie wiosennym 2011 r. wykonano w tej okolicy pierwszą refulację plaży, wysypując na odcinku ok. 1 km długości brzegu $150000 \mathrm{~m}^{3}$ piasku. Podniesiono tym samym wysokość plaży o $1 \mathrm{~m}$, a jej szerokość zwiększono do ok. $40 \mathrm{~m}$. Po intensywnych opadach deszczu w okresie letnim (w tym w lipcu), we wrześniu ponad nową opaską powstało osuwisko. Utworzyło się w górnej części klifu po zachodniej stronie tuż obok ruiny kościoła. W dolnej części plaży w wyniku zwiększonego falowania w grudniu 2011 r. utworzyło się 0,4 m wysokości podcięcie, a plaża zwęziła się o połowę, do ok. $26 \mathrm{~m}$.

Dwa spiętrzenia sztormowe ze stycznia 2012 r. powstałe przy poziomie morza 1,2 i 1,4 m nad poziom średni (sztormy o nazwie Andrea) rozmyły większą część refulowanej plaży. Opaski ochroniły klif, lecz fale sztormowe sięgały do wysokości 3,4 m n.p.m. $\mathrm{Na}$ sąsiednim odcinku bez opaski $(372,6-372,8 \mathrm{~km})$ podnóże klifu było nieznacznie podmywane przez fale sztormowe. $\mathrm{Z}$ powodu zupełnego zniszczenia plaży, latem 2012 r. wykonano nową refulację. Pod koniec lipca po intensywnych opadach deszczu, które przekroczyły $60 \mathrm{~mm}$ na dzień (Malinowska, Filipiak 2013), na ścianie klifu powstały nowe spływy gliny. Do lipca 2013 r. osad wywiewany z nowo odłożonego refulatu całkowicie pokrył opaskę z głazów i dolną część ścianki z gabionów. Wysokość plaży u podnóża klifu wzrosła do co najmniej 3,5 m n.p.m. Po intensywnych opadach, które wystąpiły w lipcu, nad zasypaną opaską powstały spływy gliny. Ponadto utworzyły się embrionalne eoliczne formy o wysokości 0,3-0,5 m, które porosła i ustabilizowała roślinność pionierska (trawy wydmowe). Na granicy tak rozbudowanej górnej plaży ze ścianą klifu rozwijały się typowe dla podłoża gliniastego siedliska łopianu i perzu (ryc. 8A).

W dniach 04/06.12.2013 r. wystąpiło ekstremalne zdarzenie meteorologiczne o nazwie Xavier. $\mathrm{W}$ tym czasie wiatr wiejący z zachodu, czyli wzdłuż brzegu i dochodzący do prędkości $20 \mathrm{~m} \mathrm{~s}^{-1}$ powodował wywiewanie dużych ilości osadu z plaży. Morze było popiętrzone znacznie, jednak nie wystąpiła erozja górnej części plaży, co wynikało z braku falowania do brzegu (wiatr i falowanie poprzecznie do brzegu). To zdarzenie spowodowało deflację refulowanej plaży, a następnie jej częściowe podtopienie i rozmycie. Powierzchnię plaży pokryło residuum deflacyjne $z$ muszli i żwiru, a w jej górnej części powstały mikroklify $z$ gwałtownego podpiętrzenia wody o wysokości $1 \mathrm{~m}$ (ryc. 6E, 7B). Do lata 2014 r. (obserwacje 05 i 08.2014) plaża miała szerokość od 25 do $32 \mathrm{~m}$ (ryc. 6F). W tym czasie na wysokości Trzęsacza zostały wykonane 3 ostrogi w celu zatrzymywania jej dalszej erozji. Opaska z narzutu głazów była całkowicie przykryta nawianym piaskiem i mogło się wydawać, że ten typ ochrony klifu jest skuteczny. Jednak w górnej jego części były widoczne nowe, niewielkie obrywy i wysięki wód gruntowych. Badania przeprowadzone przy użyciu skanera laserowego (TLS) w lipcu 2013 i 2014 r. (Łabuz 2014) na pozbawionym opaski odcinku klifu $(372,8 \mathrm{~km})$ wykazały, że ściana w okolicy Trzęsacza była pokryta licznymi mikro-spękaniami (ryc. 3B). Oznaczono kilka wysięków wód, które przyczyniały się do powstawania spływów gliny z środkowej części klifu do podnóża. Na ich podstawie możliwe było obliczenie niewielkich zmian kubatury ściany klifu na odcinku do $150 \mathrm{~m}$ jego długości. Ze względów finansowych oraz z powodu braku spiętrzeń po 2014 r. badań tych nie kontynuowano. Łącznie na monitorowanym odcinku $(372,6-372,8 \mathrm{~km})$ cofnięcie krawędzi klifu od 2012 do 2014 r. wyniosło 0,15-0,45 m.

Po spiętrzeniach sztormowych ze stycznia (Felix) i lutego (Ole) 2015 r. nastąpiło całkowite obniżenie plaż, do wysokości 1,2 m n.p.m. (ryc. 6G). Klif 

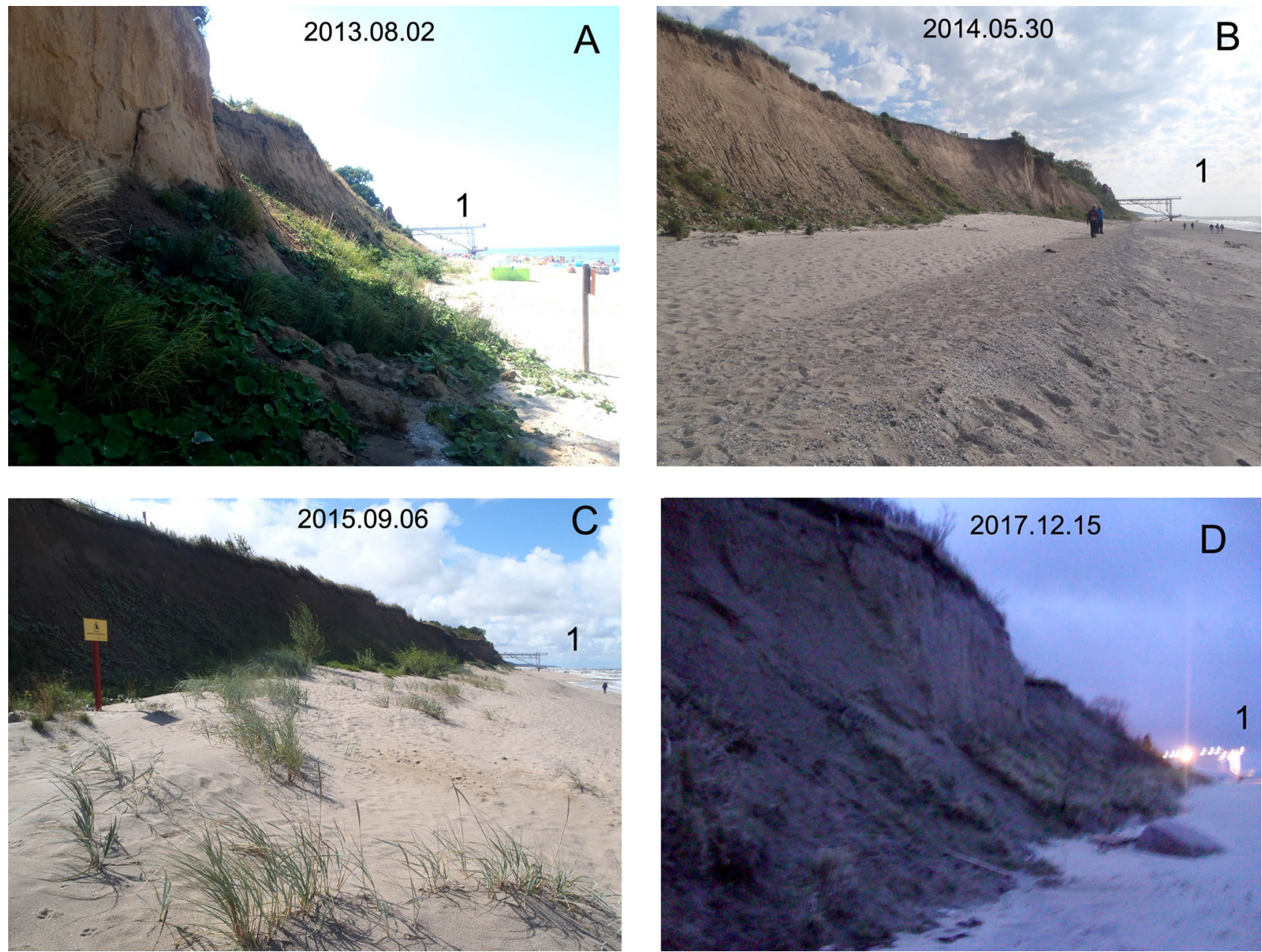

Ryc. 8. Morfologia podnóża klifu: niszczenie plaży i form podnóża klifu w okresie 2013-2017 (372,7km)

1 - taras widokowy przy ruinie kościoła. A - 2013, ustabilizowane koluwium po sztormach z 2012, B - 2014, aktywny klif i częściowo rozmyty w grudniu 2013 refulat, C - 2015, formy akumulacji eolicznej, powstające w latach 2014/15, D - 2017, aktywny klif, rozmyty refulat i podcięcia klifu spowodowały rozwój rozległego osuwiska

Fig. 8. Morphology of cliff foot: beach and foot cliff erosion in period 2013-2017 (372.7 km)

1 - observation deck near church ruin. A - 2013, stabilized colluvium after storm surges in 2012, B - 2014, active cliff and nourished Beach partially eroded in December 2013, C - 2015, aeolian accumulation developed in 2014/15, D - 2017, active cliff, washed out nourished beach and cliff cut off influenced on new landslides development

był podmywany na odcinku niechronionym opaską. Powstały spływy, które nadal rozwijały się latem w okresie opadów. Klif umocniony opaską, w dolnej części był stabilny, jednak ponad opaską z jego górnych partii również spływała glina (ryc. 7C). Pokryła ona niewielkie formy eoliczne, powstałe na opasce w okresie 2013/14. W okresie od lutego 2015 do marca 2016 r. plaże były wąskie, do 18 m szerokości. W górnej części u podnóża klifu opaska pokryta była nadal przez spływy gliny i odkładany osad eoliczny (ryc. 8C). W tym czasie ściana klifu i jego podnóże nie były niszczone.

W październiku, listopadzie, a potem grudniu 2016 r. wystąpiło 6 znaczących spiętrzeń sztormowych, które usunęły cały osad z plaży. Pierwsze spiętrzenie sztormowe $z$ poziomem morza $0,6 \mathrm{~m}$ powyżej średniego $z$ dnia 05.10 .2016 r. spowodowało obniżenie plaż. W trakcie kolejnych poziom morza był po- dobny. Spiętrzenie sztormowe o nazwie Barbara z poziomem morza 1,12 m powyżej poziomu średniego z 29/30.12.2016 r. było pierwszym od 2010 r., które zaczęło rozmywać osad zgromadzony ponad opaską. Napływające fale sięgały do 3,2 m n.p.m., czyli do 2/3 wysokości opaski (o wys. 4,2 m n.p.m.). Podczas kolejnego spiętrzenia sztormowego z 04/06.01.2017 r. o nazwie Axel poziom morza przekroczył 1,5 m ponad poziom średni. Napływająca na brzeg woda sięgała do górnej części opaski do wysokości 4 m n.p.m. erodując cały osad odłożony nad nią przez ostatnie 6 lat (ryc. $6 \mathrm{H}$ ). Klif bez osłony opaski był permanentnie podmywany. Poziom morza podczas tego spiętrzenia, sięgający 1,5 m ponad średni oraz długi okres oddzialywania na brzeg, wpierw z kierunku NW a potem NE, zniszczył plaże i wszystkie formy morfologiczne powstałe ponad opaską. Fale morskie podmywały ścianę klifu do wysokości co najmniej 3,8 m n.p.m. 

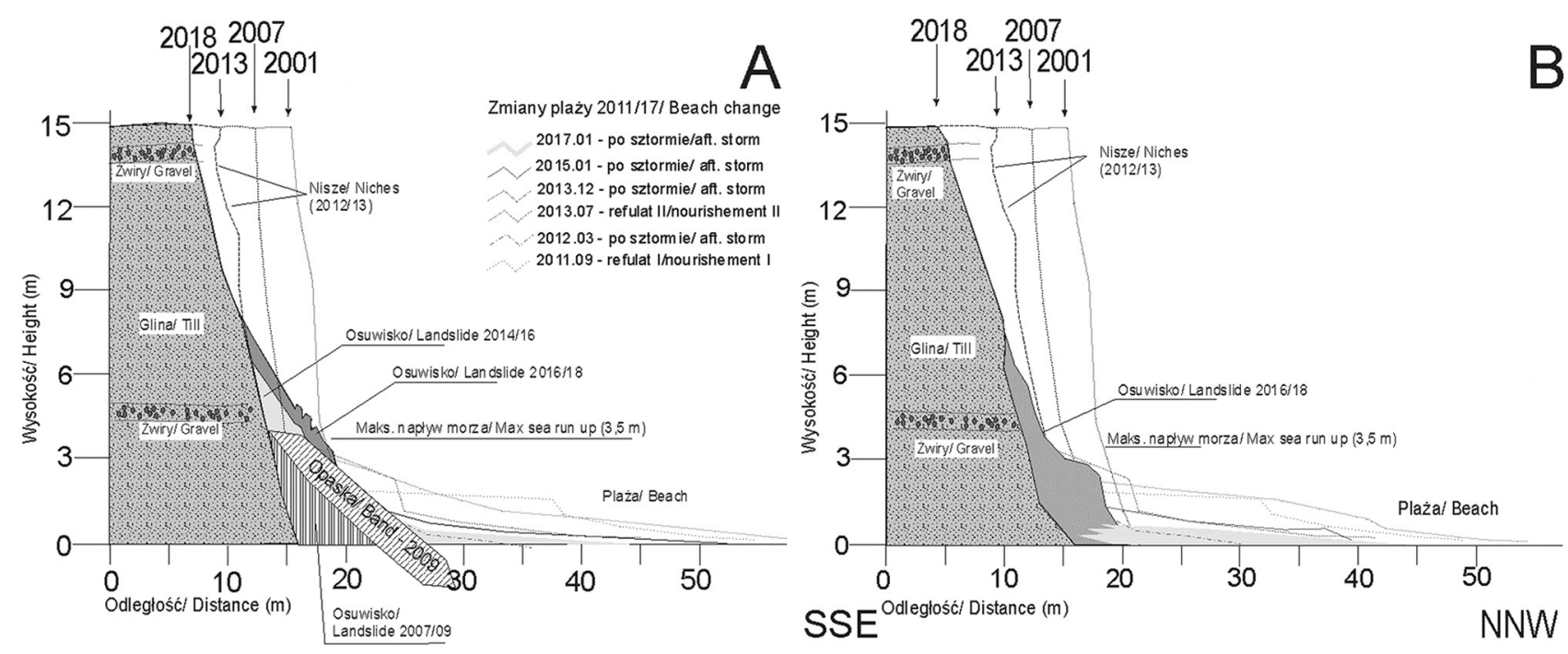

Ryc. 9. Zmiany geodynamiczne klifu w Trzęsaczu na przekroju w okresie od 2001 do 2018 roku

A - odcinek z opaską podnóża $(372,9 \mathrm{~km}), \mathrm{B}$ - ostatni odcinek naturalny $(372,75 \mathrm{~km})$

Fig. 9. Changes of geodynamic cliff cross-section in Trzęsacz for period 2001 till 2018 A - section with band $(372.9 \mathrm{~km}), \mathrm{B}$ - natural cliff section $(372.75 \mathrm{~km})$

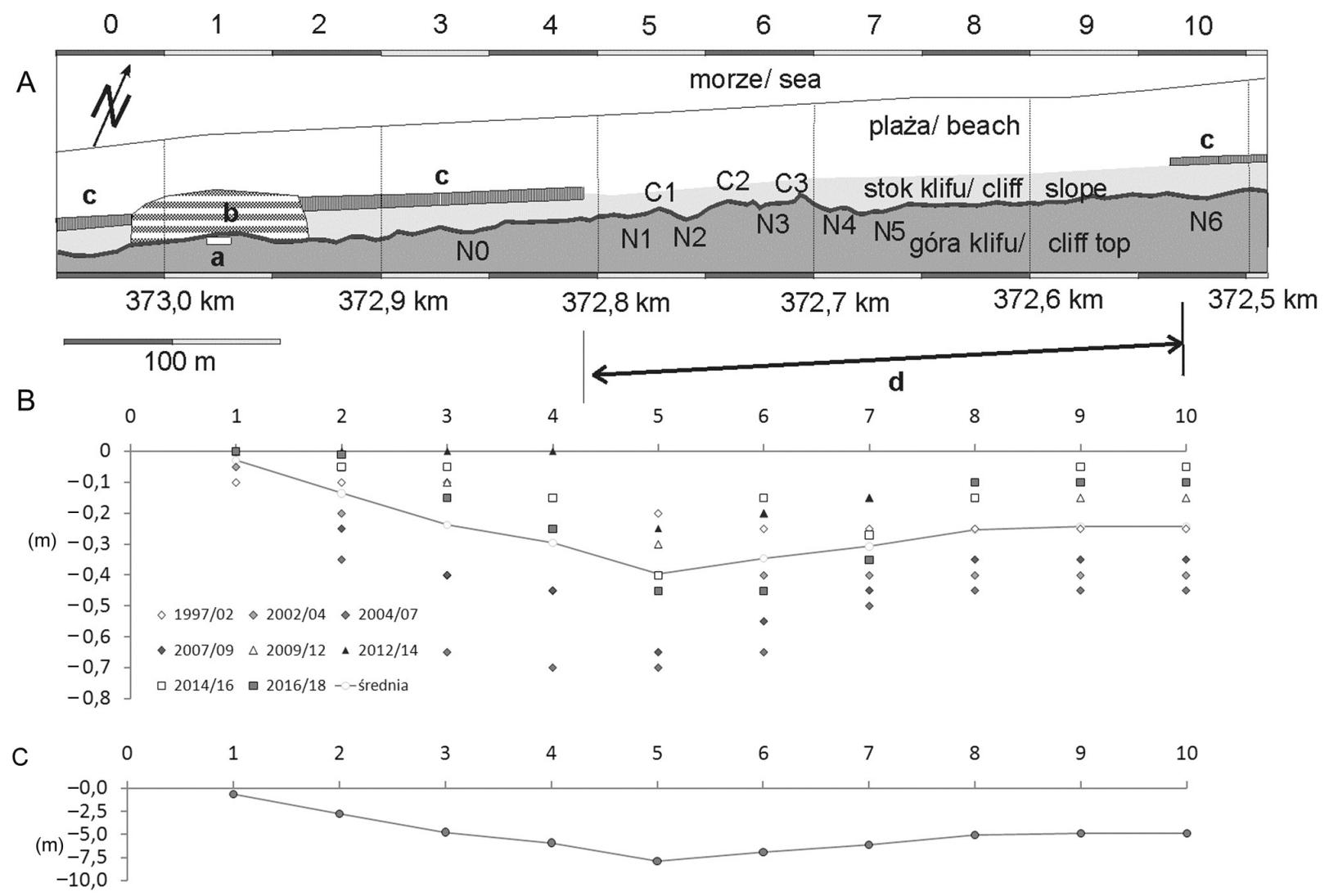

Ryc. 10. Dynamika krawędzi klifu w Trzęsaczu w okresie 1997-2017, z kilometrażem brzegu (1-10 monitorowane odcinki 50 m długości)

A - mapa krawędzi klifu na wschód od ruiny kościoła: a - położenie ruiny, b - opaska z gabionów, c - opaska z głazów, d - ostatni naturalny odcinek klifu z planowaną od 2018 opaską, N0/5 - nisze, C1/3 - występy, B - roczne tempo cofania krawędzi klifu w okresach, $\mathrm{C}$ - suma cofnięcia krawędzi klifu na monitorowanych odcinkach

Fig. 10. Cliff edge dynamic in Trzęsacz for period 1997-2017 with coast kilometrage (1-10 monitored coast sections of 50 m length)

A - map of cliff edge eastward from church ruin: a - ruin location, b - gabion's band, c - boulder's band, $\mathrm{d}$ - last natural cliff section with planned band since 2018, N0/5 - niches, C1/3 - tips, B - annual rate of edge retreat for periods, C - sum of cliff edge retreat on monitored sections 
Spowodowało to zachwianie grawitacyjnej stabilności klifu. Pierwszy raz od 2009 r. klifowa ściana, pomimo obecności opaski na wschód od ruiny w Trzęsaczu cofała się na całej wysokości. Po tym spiętrzeniu na odsłoniętej w wyniku erozji opasce znajdowało się szereg pni drewna, które rzucane przez wodę, mogły przyczyniać się do większego niszczenia ściany klifu. Przy krawędzi klif na całym badanym odcinku cofnął się od 0,15 do 0,55 m. Dotychczasowe, częściowo ustabilizowane nisze $\mathrm{w}$ górnej części stoku pogłębiły się, a w dolnej części powstały nowe, rozległe jęzory spływowe oraz rozległe osuwiska (ryc. 8D). Przy krawędzi klifu na odcinku 372,7-372,9 km powstały 0,6 m szerokości osunięcia podłoża (ryc. 7D). Plaża obniżyła się o 2-2,4 m, tym samym odsłonięte zostało podnóże klifu. Spiętrzenie sztormowe Axel było najwyższym od sztormu z listopada $1995 \mathrm{r}$. Było to również pierwsze spiętrzenie, które przelewając się ponad opaską podmywało klif, a sama opaska nie stanowiła ochrony przed erozją. Cofnięcie krawędzi klifu po sztormach z sezonu 2016/17 oszacowano średnio na $0,45 \mathrm{~m}$ (od 0,25 do $0,75 \mathrm{~m}$ ). W wyniku obniżenia plaż odsłonięte zostały dolne partie klifu, na którym powstało rozległe koluwium.

W okresie letnim 2017 r. plaże na tym i na wielu odcinkach wybrzeża nie zostały odbudowane. Ich rzędna u podnóża klifu wyniosła maksymalnie 1,2 m n.p.m. Powolne spływy gliny na stoku klifu zachodziły przez całe lato. Na początku sztormowego sezonu 2017/18 wystąpiło spiętrzenie o nazwie Grzegorz w dniach 29/31.10.2017 r. z poziomem morza $1,08 \mathrm{~m}$ ponad średni w Kołobrzegu. Podczas sztormu napływ fal sięgał na brzeg do wysokości 3,3 m n.p.m. Woda ponownie zalewała opaskę, jednak nie powodując rozmywania ściany klifu ponad nią. $\mathrm{Na}$ odcinku bez opaski, podcięte osuwiska spowodowały osunięcie całego koluwium ze ściany klifu. U jego podnóża w rozległym, spiętrzonym koluwium powstały 1,5 m wysokości podcięcia, a $\mathrm{w}$ górnej części na odsłoniętej ścianie utworzyły się nowe spływy gliny. Plaże odbudowane do jesieni zostały ponownie zupełnie zerodowane osiągając szerokość do $15 \mathrm{~m}$. W dniach 19/20.11.2017, 04/06.12.2017 i 31.12.2017 na polskim wybrzeżu wystąpiły kolejno po sobie nowe spiętrzenia sztormowe, $z$ poziomem morza przekraczającym 0,55 m nad poziom średni. Ich efektem było dalsze podmywanie spływów gliny na odcinku klifu bez osłony opaski, co było spowodowane przelewaniem wody ponad niską plażą (ryc. 6I, 7D, 8D). Od lipca do grudnia 2017 r. krawędź klifu na odcinku nieosłoniętym opaską cofnęła się średnio od 0,2 do $0,35 \mathrm{~m}$, a na osłoniętym o około $0,1 \mathrm{~m}$.

Łącznie w okresie od 2010 do 2017 erozja krawędzi klifu nieosłoniętego opaską (372,6-372,8 km) wyniosła $0,15-0,45 \mathrm{~m} \mathrm{a}^{-1}$. Było to efektem przede wszystkim opadów i wysięków wód opadowych W górnej części nieosłoniętego roślinnością klifu.
W wyniku powolnego cofania klifu, jego nachylenie zwiększało się do czasu usunięcia koluwium z podnóża przez kolejne spiętrzenie sztormowe. $\mathrm{Na}$ odcinku z opaską u podnóża $(372,8-372,9 \mathrm{~km})$ krawędź cofała się tylko po większych opadach i po spiętrzeniach z sezonu 2016/17. Od czasu zbudowania opaski krawędź cofnęła się względem podstawy o 0,5 do $1 \mathrm{~m}$. $\mathrm{Na}$ odcinku brzegu bez ochrony, klif cofnął się nawet do $2 \mathrm{~m}$. Było to skutkiem przede wszystkim spiętrzenia Axel ze stycznia 2017 r. Łącznie w okresie 19972017 klif na odcinku 500 m, położnym na wschód od ruiny kościoła cofnął się o ponad 5-8 m (ryc. 9, 10). $\mathrm{Na}$ zakończeniu opasek erozja była zawsze większa. Erozji klifu nie było na odcinku osłoniętym ścianką z gabionów. Bez tej konstrukcji u podnóża dawnego kościoła, ostatnia jego ściana byłaby zniszczona podczas spiętrzeń w 2007 lub 2012 r.

\section{Dyskusja}

Współcześnie największe zmiany erozyjne klifu zbudowanego $z$ glin morenowych o bardzo skomplikowanej strukturze pomierzono w Jastrzębiej Górze, gdzie po intensywnych opadach powstało rozległe osuwisko, z krawędzią klifu cofającą się aż $20 \mathrm{~m}$ w latach 2010/12 (Uścinowicz i in. 2014). Osuwisko to jest nadal aktywne i zniszczyło zupełnie zastosowane $\mathrm{w}$ poprzednich latach formy ochrony podnóża i drenażu ściany klifu. Duże zmiany morfologii po opadach deszczu obserwowano również na wysokich piaszczysto-gliniastych klifach Wyspy Wolin (Winowski 2015). Największe średnie, roczne tempo cofania krawędzi klifu na Wolinie dochodzi do $2 \mathrm{~m}$ (Kostrzewski i in. 2015). Mniejsze zmiany pomierzono na klifach niższych, składających się przede wszystkim z samych glin. Niski klif zbudowany z glin w okolicy Pleśni (rejon Gąsek) w okresie 2006/15 cofał się z prędkością 0,2-0,4 $\mathrm{m} \mathrm{a}^{-1}$ i maksymalnie o 0,6 m (Suchocki i in. 2016). Większe ubytki rejestrowano u jego podnóża niż na krawędzi. Był to okres wystąpienia na polskim wybrzeżu kilku znaczących spiętrzeń sztormowych, w 2006, 20072009 i 2012 r. (Łabuz 2012b, 2015). Na wybrzeżu środkowym, w okolicy Dębiny największe zmiany klifu, zarejestrowane w okresie 1998/07 wynosiły maksymalnie do $0,9 \mathrm{~m} \mathrm{a}^{-1}$ (Florek i in. 2008). Zmiany były największe po spiętrzeniach sztormowych z 2004, 2006 i 2007 r. Tempo cofania klifu zależało także od jego budowy geologicznej. Klif $z$ warstwami piasków cofał się dwukrotnie szybciej niż zbudowany tylko z glin (Florek i in. 2008, Suchocki i in. 2016). Wyniki kartowania klifu in situ metodami TLS oraz analizy map z odcinka klifu w okolicy Orzechowa wskazują, że tempo erozji w czasie jest zmienne, od 0,6 do nawet $4,6 \mathrm{~m} \mathrm{a}^{-1}$ (Frydel i in. 2017). W okre- 
sie 1997-2017 największy ubytek klifu w Trzęsaczu wynosił do $0,8 \mathrm{~m}$ po sztormie, a średnio $0,4 \mathrm{~m} \mathrm{a}^{-1}$. Wpływ na wielkość erozji miała wysokość plaży nad poziom morza. Wyższe plaże, min. 3 m n.p.m., zawsze chroniły podnóże przed działaniem napływu fal. W latach bezsztormowych klif w okolicach Trzęsacza okresowo stabilizował się. Po opadach deszczu w okresie wiosenno-letnim, również obserwowano znaczny ubytek materiału na jego krawędzi, w tym np. w 2007 r. Średnie, roczne tempo cofania krawędzi klifu w okolicy Trzęsacza $z$ wielolecia wynosi ok. 0,4 m. Wartość podobną określono również na podstawie pomiarów kartometrycznych z map (Zawadzka-Kahlau 1999). Jest to znacznie mniej niż podawane średnie tempo cofania polskiego wybrzeża, określone na około $0,9 \mathrm{~m} \mathrm{a}^{-1}$. Największe cofanie krawędzi klifu o wartości $0,6-0,9 \mathrm{~m}$ pomierzono po spiętrzeniach sztormowych z 2007, 2009 i 2017 r. Z badań na innych odcinkach wybrzeża klifowego o bardziej skomplikowanej budowie geologicznej wynika, że w ostatnich latach tempo erozji jest większe, i okresowo dochodzi nawet do 3-4 $\mathrm{m} \mathrm{a}^{-1}$ (Florek i in. 2008, Uścinowicz i in. 2014, Frydel i in. 2017). Przyczyniają się do tego częstsze okresy występowania po sobie 2-3 spiętrzeń sztormowych w ciągu jednego sezonu. Duże znacznie odgrywa również niestabilna budowa geologiczna, która w przeciwieństwie do odcinka klifu w okolicy Trzęsacza charakteryzuje dynamiczne klify typu spływowo-obrywowego wg klasyfikacji Subotowicza (1982).

Po wybudowaniu w Trzęsaczu w 2010 r. opaski u podnóża klifu, tuż obok ruiny kościoła erozja morska ustała. Nadal jednak występowała powolna erozja jego krawędzi powstająca w wyniku inicjowanych opadami ruchów masowych (ryc. 9). Zaobserwowana wzmożona erozja na odcinku naturalnym, bezpośrednio sąsiadującym $z$ opaską wskazuje na intensyfikację, wynikającą $z$ odbicia fali od przeszkody. Takie samo zjawisko erozji na zakończeniu osłony klifu obserwowano po wybudowaniu ścianki szczelnej w 2004 r. Największe, dochodzące do 0,7 $\mathrm{m} \mathrm{a}^{-1}$ po sztormach z 2007 i 2009 r. (ryc. 10). Klif nieosłonięty opaską uległ znacznej erozji po kilku następujących po sobie spiętrzeniach sztormowych z okresu jesienno-zimowego 2016/17. Doszło do tego po uprzednim usunięciu przez fale refulowanej pla$\dot{z}$ y, która w poprzednich latach skutecznie osłaniała stopę klifu przed podmywaniem. W analizowanych pracach naukowych również podkreśla się wzrost intensywności erozji po kilku znaczących spiętrzeniach sztormowych.

Faktem jest, że na wierzchowinie niskich wysoczyzn plejstoceńskich (zbudowanych z glin) procesy geodynamiczne nie są bardzo aktywne, najczęściej mamy do czynienia z sączeniem wód i spływem uwodnionego osadu (Racinowski, Pozlewicz 2000). Jednak aktywne procesy $\mathrm{w}$ strefie kontaktu morza z podnóżem klifu stanowią zagrożenie dla stabilności jego krawędzi i ewentualnych inwestycji inżynierskich (Racinowski, Pozlewicz 2000). Bezpieczne inwestowanie w tej okolicy - dokładnie w Trzęsaczu powinno być zlokalizowane od 50 do $100 \mathrm{~m}$ (Racinowski, Pozlewicz 2000) lub od 100 do $200 \mathrm{~m}$ (Dubrawski, Zawadzka-Kahlau 2006) od krawędzi klifu. Obszar ten, jak widać posiada wiele cech środowiska niebezpiecznego dla działalności człowieka i mogącego prowadzić do strat materialnych, a nawet zagrożenia życia (znane są wypadki śmiertelne spowodowane obsunięciem mas skalnych klifu, np. Rugia - Niemcy, Portugalia). Należy więc podkreślić, że badania i ochrona brzegu morskiego nie mogą być domeną jednej gałęzi wiedzy, jest to zagadnienie złożone i interdyscyplinarne (Subotowicz 1995).

Jak wykazano powyżej intensywne i ciężkie prace na odcinku Rewal-Trzęsacz umożliwiły powstrzymanie morskiej erozji podnóży klifu. Nie zatrzymało to jednak powolnej erozji krawędzi klifu. Plaże mimo cyklicznych refulacji są nadal wąskie i nisko położone nad poziom morza. Po obecnej zabudowie podnóża klifu opaską, zaniechanie refulacji będzie powodować powolne zatapianie kamieni opaski $\mathrm{w}$ gruncie. Dotychczas zainwestowano duże środki finansowe i poczyniono znaczne prace hydrotechniczne, które na zawsze zmieniły krajobraz ale i dynamikę klifu na odcinku Trzęsacz-Niechorze. W warunkach obserwowanych i prognozowanych zmian klimatu te zabiegi mogą być niewystarczające. Dowodem tego są obserwowane warunki powstawania erozji klifu w ostatnim roku okresu badawczego, tj. w 2017. Prawdopodobnie $\mathrm{w}$ związku z sukcesywnym niszczeniem refulowanych plaż i powstaniem w styczniu 2017 r. osuwisk na ostatnim, naturalnym odcinku klifu $(372,55-372,8 \mathrm{~km})$, w grudniu 2017 r. ogłoszono plan budowy opaski i na tym ostatnim odcinku. Niestety w ten sposób bezpowrotnie zostanie zmieniony naturalny krajobraz i procesy kształtujące wybrzeże klifowe w okolicach Niechorze-Trzęsacz.

Procesy kształtujące klif nadmorski i ich tempo są trudne do przewidzenia, zwłaszcza przy zmianach klimatu i wzmożeniu aktywności sztormowej. Ryzyko wystąpienia sztormu $z$ wodą tzw. 100-letnią w ciągu 22 lat zaistniało 2-krotnie. Zmiany pomierzone wskazują na stały, powolny ubytek krawędzi klifu przez okres omawianych 20-stu lat. Od roku 2001 do 2009 erozja podnóża klifu bez zabiegów hydrotechnicznych wyniosła 8-12 m, tj. maksymalnie ok. 1,2 m rocznie. Od 2010 r. podnóże klifu w wyni$\mathrm{ku}$ posadowienia opaski nie było erodowane. Skutkiem posadowienia opasek było wzmożone tempa cofania klifu, na wschód od ich zakończenia (wpierw w 2004, a następnie w 2010 r.). Krawędź klifu w tej okolicy ma kręty przebieg i cechują ją rozwijające się sukcesywnie i pogłębiające się nisze. Górna krawędź klifu od 2010 do 2016 cofała się ok. 0,15-0,45 $\mathrm{m} \mathrm{a}^{-1}$. 


\section{Podsumowanie}

Celem opracowania jest przedstawienie dotychczasowych zmian geodynamicznych klifu w okolicy Trzęsacza oraz określenie współczesnej jego morfodynamiki wynikającej ze zmian klimatycznych. Ustalono, że najczęstsze procesy morfodynamiczne, kształtujące klif morenowy badanego odcinka, to różnorodna erozja rozumiana jako:

- podcinanie stopy klifu przez fale morskie (abrazja): w ścianie klifu powstają nisze abrazyjne i różnorodne osuwiska, u jej podnóża powstaje platforma abrazyjna, okresowo przykrywana osadem odkładanym przez morze lub wiatr,

- grawitacyjne ruchy masowe: obrywanie, spływ materiału odspojonego od ścian klifu w wyniku różnorodnych czynników zewnętrznych,

- rozmywanie przez przesiąkające i wypływające z ścian klifu wody gruntowe, a zwłaszcza opadowe (w tym sufozja, wypłukiwanie nowych szczelin),

- wietrzenie mechaniczne - wiatrowe przez wywiewanie luźnego osadu, ewentualnie korazja dolnej części ściany klifu przez procesy eoliczne,

- wietrzenie biologiczne - rozrywanie spójności osadu przez korzenie drzew lub krzewów, w tym obalanych przez wiatr lub ruchy masowe, tworzących rozległe wykroty, najczęściej w górnej części stoku klifu.

Erozję zachodzącą $z$ powodu człowieka można podzielić na związaną z:

- budowlami i infrastrukturą przy krawędzi klifu: odprowadzanie wód opadowych i ścieków do gruntu, drgania $z$ transportu kołowego, rozcinanie i blokowanie warstw wodonośnych oraz destabilizacja podłoża budowlami, w tym przez głębokie fundamenty, obciążanie krawędzi obiektami,

- stosowaniem zabiegów hydrotechnicznych stabilizacji stopy lub ściany klifu w jednym miejscu i w konsekwencji wzmożenie erozji na zakończeniu takiego umocnienia - w wyniku oddziaływania fali nałożonej i odbitej od opaski czy falochronu.

Refulowane plaże u podnóża klifu są najmniej inwazyjną ostateczną formą ochrony, ale są niszczone przez spiętrzenia sztormowe. Opaski od 2010 r. chronią podnóże klifu przed cofaniem lecz nie chronią jego krawędzi. To opady deszczu powodują obecnie erozję klifu - powstawanie spływów ze ścian położonych ponad kamienną opaską. Klif naturalny położony tuż na zakończeniu opaski, wpierw tej z 2004, a następnie z 2010 r. ulegał szybszemu cofaniu. Przebieg jego krawędzi wskazuje na wyraźne wklęśniecie $\mathrm{w}$ odległości $200 \mathrm{~m}$ od ruiny kościoła. Ścianka szczelna powstrzymała cofanie całego stoku klifu, jest jednak wyjątkowym zabiegiem, zastosowanym dla ochrony ściany kościoła.

Główne czynniki oddziałujące na geodynamikę klifu to uwarunkowania meteorologiczne i hydrolo- giczne. Spiętrzenia sztormowe powodują podcinanie podnóża klifu i rozwój ruchów masowych. Nie występują one co roku, co umożliwia okresową stabilizację ścian klifu. Największą erozję notowano po kilku następujących po sobie spiętrzeniach sztormowych. Groźnym czynnikiem są okresowe ekstremalne opady i ewentualnie roztopy powodujące powstawanie spływów na osi wysięków wód gruntowych. Wielkość i tempo erozji klifu wynika z nieprzewidywalnych uwarunkowań pogodowych, wywoływanych przez zmiany klimatyczne. W okresie 20-tu lat pomiędzy 1997-2017 tempo erozji krawędzi klifu morenowego na tym odcinku wyniosło średnio $0,4 \mathrm{~m} \mathrm{a}^{-1}$.

\section{Posłowie}

Pracę tę dedykuję pamięci Profesora Romana Racinowskiego, zmarłego w listopadzie 2017 r., który przez wiele lat prowadził badania na wybrzeżu zachodnim Polski, w tym na odcinku wybrzeża morenowego w okolicy Trzęsacza. Jego badania i wyniki stały się inspiracją w mojej pracy naukowej. Dzięki publikacjom naukowym Profesora uzyskaliśmy szereg cennych informacji o rozwoju zachodniego wybrzeża Polski.

\section{Literatura}

Bohdziewicz L., 1963. Przegląd budowy geologicznej i typów polskich wybrzeży. W: A.Mielczarski (red.), Materiały do monografii polskiego brzegu morskiego, 5. Geologia i zagadnienia pokrewne, IBW PAN, Gdańsk-Poznań: 10-41.

Boniecka H. (red.), 2013. Monitoring i badania dotyczące aktualnego stanu brzegu morskiego - ocena skuteczności systemów ochrony brzegu morskiego zrealizowanych w okresie obowiązywania wieloletniego: Programu ochrony brzegów morskich, IBW PAN, Gdańsk: 1-250.

Dobracka E., Dobracki R., 1995. Geology and geodynamic of the cliff coast between Niechorze-Trzęsacz. W: K.Rotnicki (red.) Polish coast: past, present, future. Journal of Coastal Research Special Issue 22: 283-285.

Dobracka E., Ruszała M., 1988. Charakterystyka geologiczna i geomorfologiczna strefy przymorskiej na odcinku Międzyzdroje-Trzęsacz-Niechorze. Prace Naukowe Pomorsko-Szczecińskie 378: 17-52.

Dobracki R., 1995. Geology and geodynamic of the cliff coast between Niechorze-Trzęsacz. W: K.Rotnicki (red.), Polish coast: past, present, future, Journal of Coastal Research Special Issue 22: 283-285.

Dobracki R., 1999. Rozwój brzegu i geologia klifu okolic Trzęsacza. W: R.K.Borówka, Z.Młynarczyk, A.Wojciechowski (red.), Ewolucja geosystemów nadmorskich południowego Bałtyku. Bogucki wydawnictwo Naukowe, Poznań-Szczecin: 69-71.

Dobracki R., Racinowski R., 1989. Czwartorzędowe powierzchnie morfogenetyczne wysoczyzny rejonu Rewala. Studia i Materiały Oceanologiczne 56: 151-161.

Dubrawski R., Zawadzka E., 2006. Przyszłość ochrony polskich brzegów morskich. Wydawnictwo Naukowe Instytutu Morskiego w Gdańsku, Gdańsk: 1-302.

Dudzińska-Nowak J., Furmańczyk K., 2005. Zmiany położenia linii brzegowej Zatoki Pomorskiej (w latach 1938-1996). W: R.K.Borówka, S.Musielak (red.), Srodowisko przyrodnicze wy- 
brzeży zatoki Pomorskiej i Zalewu Szczecińskiego. Wybrane aspekty. PTG, Instytut Nauk o Morzu US, Wyd. Oficyna In Plus, Szczecin: $72-78$.

Dudzińska-Nowak J., Wężyk P., 2014. Volumetric changes of a soft cliff coast 2008-2012 based on DTM from airborne laser scanning (Wolin Island, southern Baltic Sea). Journal of Coastal Research Special Issue 70: 59-64.

Florek W., Kaczmarzyk J., Majewski M., Olszak I.J., 2008. Zmiany rzeźby klifu w rejonie Ustki jako efekt warunków litologicznych oraz procesów ekstremalnych i przeciętnych. Landform Analysis 7: $53-68$.

Frydel J.J., Mil L., Szarafin T., Koszka-Maroń D., Przyłucka M., 2017, Zmienność czasowa i zróżnicowanie przestrzenne wielkości i tempa erozji klifu Zatoki Usteckiej w rejonie Orzechowa, Landform Analysis 34: 3-14.

Girjatowicz J.P., 1999. Structural variability of near-shore ice and its abrasive effects in sheltered and exposed areas. Late Glacial, Holocene and present-day evolution of the coastal geosystems of the Southern Baltic. W: R.K.Borówka (red.), Late Glacial, Holocene and present-day evolution of the coastal geosystems of the Southern Baltic. Quaternary Studies in Poland Special Issue: 103-107.

Hartnack W., 1926. Die Küste Hinterpommerns unter besonderer Berücksichtigung der Morphologie. Jahrbuch der Geographischen Gesellschaft 43/44.

Kolander R., 2013. Zastosowanie skaningu laserowego w pomiarach ilościowych abrazji na klifowym odcinku wyspy Wolin. W: A.Kostrzewski, Zb.Zwoliński, M.Winowski (red.), Geoekosystem wybrzeży morskich 2, Wyd. UAM, Poznań-Biała Góra: 53-58.

Kolander R., Morche D., Bimböse M., 2013. Quantification of moraine cliff erosion on Wolin Island (Baltic Sea, northwest Poland). Baltica 26(1): 37-44.

Kopczyńska-Lamparska K., 1974. Geneza i stratygrafia glin zwałowych klifu okolic Rewala. Zeszyty Naukowe UAM Geografia 10: 167-176.

Kostrzewski A., Zwoliński Zb., 1987. Formy erozyjnej i akumulacyjnej działalności wód na wybrzeżu klifowym wyspy Wolin (propozycja klasyfikacji). Sprawozdania PTPN 104: 72-75.

Kostrzewski A., Zwoliński Zb., 1988. Morphodynamics of cliffed coast, Wolin Island. Geographia Polonica 55: 69-81.

Kostrzewski A., Zwoliński Zb., 1995. Present-day morphodynamics of the cliff coasts of Wolin Island. W: K.Rotnicki (red.), Polish coast: past, present, future, Journal of Coastal Research Special Issue 22: 293-303.

Kostrzewski A., Zwoliński Zb., Winowski M., Tylkowski J., Samotyk M., 2015. Cliff top recession rate and cliff hazards for the sea coast of Wolin Island (Southern Baltic). Baltica 28 (2): 109-120.

Kowalewska-Kalkowska H., Kowalewski M., 2005. Operational hydrodynamic model for forecasting extreme hydrographic events in the Oder Estuary. Nordic Hydrology 36(4-5): 411-422.

Krzyszkowski D., Dobracka E., Dobracki R., Czerwonka J.A., Kuszell T., 1999. Stratigraphy of Weichselian deposits in the cliff sections between Łukęcin and Niechorze, Baltic coast, northwestern Poland. Quaternary Studies in Poland 16: 27-45.

Łabuz T.A., 2012a. Klify nadmorskie na wybrzeżu Bałtyku. W: W.Mróz (red.), Monitoring siedlisk przyrodniczych. Przewodnik metodyczny. Część II. GIOŚ, Warszawa: 40-58.

Łabuz T.A., 2012b. Coastal response to climatic changes: Discussion with emphasis on southern Baltic Sea. Landform Analysis 21: 43-55.

Łabuz T.A., 2013. Sposoby ochrony brzegów morskich i ich wpływ na środowisko przyrodnicze polskiego wybrzeża Bałtyku. Wyd. Fundacja WWF, Warszawa: 1-178.

Łabuz T.A., 2014. Zastosowanie naziemnego skaningu laserowego w badaniach morfografii klifowych i wydmowych nadbrzeży morskich. W: II Sympozjum Morskiej Geomorfologii. Poziom Morza, linia brzegowa, 24.10.2014. Instytut Morski w Gdańsku.

Łabuz T.A., 2015. Environmental impacts - Coastal erosion and coastline changes. W: BACC II Team (eds.), Second Assessment of Climate Change for the Baltic Sea Basin. Springer: 381-396.
Malinowska M., Filipiak J., 2013. Wybrane ekstremalne zjawiska meteorologiczne $\mathrm{W}$ strefie brzegowej Południowego Bałtyku w latach 2001-2011 W: A.Kostrzewski, Zb.Zwoliński, M.Winowski (red.), Geoekosystem wybrzeży morskich 2, Wyd. UAM, Poznań-Biała Góra: 72-79.

Musielak S., 1995. Shoreline dynamics between Niechorze and Świnoujście. W: K.Rotnicki (red.), Polish coast: past, present, future. Journal of Coastal Research Special Issue 22: 289-291.

Musielak S., Łabuz T.A., Wochna S., 2005. Współczesne procesy brzegowe na Wybrzeżu Trzebiatowskim. W: R.K.Borówka, S.Musielak (red.), Środowisko przyrodnicze wybrzeży zatoki Pomorskiej i Zalewu Szczecińskiego. Wybrane aspekty. PTG, Instytut Nauk o Morzu US, Wyd. Oficyna In Plus, Szczecin: 61-71.

Racinowski R., 1990. Uwagi o wpływie cech hydrogeologicznych podłoża na rozwój strefy brzegowej w rejonie Rewala. Przegląd Geologiczny 11: 492-495.

Racinowski R., 1996a. Tentative dynamic interpretation of lithological study of nearshore deposits between Niechorze and Trzęsacz. W: Z.Meyer (red.), Lithodynamics of Seashore. Technical University of Szczecin, Zapol Print, Szczecin: 5-26.

Racinowski R., 1996b. Remarks on influence of hydrogeological properties of the undershore on shore zone development in the Rewal region. W: Z.Meyer (red.), Lithodynamics of Seashore. Technical University of Szczecin, Zapol Print, Szczecin: 39-46.

Racinowski R., Dobrzyński S., Coufal R., 1993. Wybrane aspekty geologiczne planowania i realizacji osadnictwa w rejonie nadmorskim. Słupskie Prace Matematyczno-Przyrodnicze 9c, Geografia, Wyższa Szkoła Pedagogiczna w Słupsku: 21-41.

Racinowski R., Pozlewicz A., 2000. Geologiczno-geotechniczne aspekty wyznaczania stref ochronnych w geosytemie nadmorskim wybrzeża szczecińskiego. W: W.Florek (red.), Geologia i geomorfologia Pobrzeża i południowego Bałtyku, WSP Słupsk, 5: 215-229.

Racinowski R., Seul C., Cedro B., 1995, Niektóre cechy litologiczne osadów klifu w Śliwinie. W: W. Florek (red.), Geologia i geomorfologia Pobrzeża i południowego Bałtyku, WSP Słupsk, 2: 257-268.

Rotnicki K., 1995. Ruins of the Mediaeval church at Trzęsacz and the intensity of cliff abrasion over the last few hundred years. W: K.Rotnicki (red.), Polish coast: past, present, future. Journal of Coastal Research Special Issue 22: 287-295.

Subotowicz W., 1982. Litodynamika brzegów klifowych wybrzeża Polski. Ossolineum, Gdańsk: 1-153.

Subotowicz W., 1995. Geologiczno-inżynierskie aspekty rozwoju i ochrony brzegów klifowych w Polsce. W: W.Florek (red.), Geologia i geomorfologia Pobrzeża i południowego Bałtyku, WSP Słupsk, 2: 281-284.

Suchocki Cz., Damięcka-Suchocka M., Jerzakowska A., Gawron W., 2016. Ocena dynamiki zmian brzegu klifowego położonego w pobliżu miejscowości Pleśna w latach 2006-2015. Biuletyn WAT LXV(2): 155-166.

Szopowski Z., 1961. Zarys historycznych zniszczeń polskich morskich brzegów klifowych. Materiały do monografii polskiego brzegu morskiego 1.

Tomczak A., 1995. Geological structure and Holocene evolution of the Polish coastal zone, W: K.Rotnicki (red.), Polish coast: past, present, future, Journal of Coastal Research Special Issue 22: 15-31.

Uścinowicz G., Kramarska R., Kaulbarsz D., Jurys L., Frydel J., Przezdziecki P., Jegliński W., 2014. Baltic Sea coastal erosion; a case study from the Jastrzębia Góra region. Geologos 20(4): 259-268.

Winowski M., 2008. Geomorfologiczne skutki tajania pokrywy śniegu na wybrzeżu klifowym wyspy Wolin. Landform Analysis 9: 222-225.

Winowski M., 2015. Aktywność procesów osuwiskowych na wybrzeżu klifowym wyspy Wolin w warunkach oddziaływania zdarzeń hydrometeorologicznych o wysokim potencjale morfogenetycznym (Zatoka Pomorska - Bałtyk Południowy). Landform Analysis 28: 87-102. 
Wolski T., 2017. Czasowa i przestrzenna charakterystyka ekstremalnych poziomów wód Morza Bałtyckiego. Uniwersytet Szczeciński Rozprawy i Studia MXXVI(952): 1-265.

Zawadzka-Kahlau E., 1999. Tendencje rozwojowe polskich brzegów Bałtyku Południowego. IBW Gdańsk: 1-147.
Zeidler R.B., Wróblewski A., Miętus M., Dziadziuszko Z., Cyberski J., 1995. Wind, wave, and storm surge regime at the Polish Baltic coast. W: K.Rotnicki (red.), Polish coast past, present, and future, Journal of Coastal Research Special Issue 22: 33-54. 